\title{
Can cultural significance in plants be explained by domestication and usage spaces? A study case from a coffee producing community in Huila, Colombia
}

\author{
Jeison H. Rosero-Toro ${ }^{1}$, Hilda del Carmen Dueñas Gómez ${ }^{1}$, Felipe Ruan-Soto ${ }^{2}$ \\ and Dídac Santos-Fita ${ }^{3 *}$
}

\begin{abstract}
This study was aimed at delving into the relationship between botanical species with cultural significance and both the managed environments they inhabit (Coffee plantation, Forest, Garden, Orchard, Market) and their origin (Wild, Cultivated), as established by people from vereda Las Delicias, Colombia. We tested the hypothesis that cultivated plants from the coffee plantations would have the highest cultural significance. One hundred and ninety-two plants were recorded by common name, however, upon taxonomic analysis, 238 botanical species were established. The most relevant spaces in terms of diversity were the coffee plantation (91 useful plants) and the garden (81 useful plants). Regarding origin, most of the plants were cultivated (151), with only 50 wild species. Likewise, there is a significantly larger cultural significance of coffee plantantion plants than there is garden plants and forest plants. Furthermore, cultivated plants have a significantly larger cultural significance than do wild plants. In conclusion, there is a diversity of useful plants within coffee plantation systems, which guarantee family livelihoods, diversify income sources, and protect the natural resources of the region. Finally, the importance of coffee (Coffea arabica L.) comes from its role as a customary heritage for this community, which strengthens agricultural, environmental, and cooperative processes after each generation.
\end{abstract}

Keywords: Ethnobotany; Ethnobotanical Categories; Local Knowledge; Management and Use; Coffee Cultivation.

1 Grupo de Investigación y Pedagogía en Biodiversidad, Universidad Surcolombiana, Avenida Pastrana Borrero con Cra.1, Neiva, Huila, 41001, Colombia.

2 Instituto de Ciencias Biológicas, Universidad de Ciencias y Artes de Chiapas, Libramiento Norte Poniente 1150, Colonia Lajas Maciel, Tuxtla Gutiérrez, Chiapas, 29039, Mexico.

3 Instituto Amazônico de Agriculturas Familiares, Universidade Federal do Pará, Rua Augusto Corrêa 01 - Guamá, Belém, PA, 66075-110, Brazil.

* Corresponding author $₫$. E-mail address: JHRT (jroserotoro3@gmail.com), HCDG (hildugo@gmail.com), FRS (ruansoto@yahoo.com.mx), DSF (dsantofi@gmail.com). 


\section{SIGNIFICANCE STATEMENT}

The manuscript presents relevant information for the understanding of ethnobotanical practices developed by a rural community in Colombia. It provides knowledge about the species used within ethnobotanical categories and a quantified value of the cultural significance of the useful flora in its diverse managed spaces. In addition, it analyzes the relationship between culturally significant plants and managed spaces, as well as that between culturally significant plants and their domestication status. Furthermore, it tests the hypothesis that, for this community, plants that are cultivated and those within the coffee plantations are assigned higher significance values than wild plants within forests or in other managed spaces. Colombia is widely recognized as a highquality coffee producer, however, studies that bring attention to the value of the complexity of the coffee plantation systems and the rural traditions behind them, are not numerous and quite recent. Therefore, this study provides a compelling argument for the significance of this crop, as well as the ancestral heritage that has transformed Coffea arabica L. production into a way of strengthening agricultural, environmental and rural processes throughout generations.

\section{INTRODUCTION}

The recognition of useful flora and the preference for certain plants by different social groups makes it possible to generate a critical starting point for the design of conservation actions within transformed areas, which could lead to greater interest and participation by local populations (Castellano 2011). Upon these scenarios, ethnobotany serves as a bridge between local knowledge and rural traditions associated to the use and management of vegetable species; the ethnobotanical heritage has an important role as an element of identity and a benchmark for local cultures (Pardo de Santayana and Gómez 2003). This knowledge continues to be a reliable and valuable source to learn about vegetation dynamics and it is the basis for the management of local resources (Wezel and Lykke 2006).

Thus, a culturally significant plant may be defined as a plant species that is desired, preferred or highly regarded in terms of affection by most members of a specific culture (Tardío and Pardo de Santayana 2008), which may also relate to ecological, cultural, and genetic factors that shape behavior and species selection according to adaptative memory and cultural affinity (da Silva et al. 2020). Moreover, the significance of a species can be explained by diverse factors such as the number of uses as per ethnobotanic category, availability, acces to the resource, or its origin (Rosero-Toro et al. 2018a). Therefore, ethnobotanists have begun to study local knowledge incorporating quantitative analyses, which make it possible to evaluate the relationship between biological and cultural diversity, as well as the relative significance of natural resources for a local population (Medeiros et al. 2011). To evaluate the cultural significance of diverse organisms (plants, animals and mushrooms) quantitatively, different indicators have been proposed. One such proposal is the Frequency of Mention, based on the premise that the more important an organism is for a community, the more likely it will be named in a free listing (García del Valle et al. 2015; Ruan-Soto 2020; Weller and Romney 1988). The elements which are mentioned most frequently are assumed to be of greater cultural significance to the studied population (Hilgert 2007; Thompson and Juan, 2006)

Over the last few decades, increased worldwide efforts have been made to recognize the cultural significance of plant species (e.g., Albuquerque et al. 2020; Cruz-Pérez et al. 2021; León-Merino et al. 2017; Mendoza et al. 2020); however, a deeper focus on agroforest systems, such as shade coffee plantations, is required. Shade coffee plantantions are deemed important refuges for biodiversity (De Beenhouwer et al. 2013) as they contain varied useful species which can be potentially commercialized (Martínez et al. 2007) and preserved. Consequently, local communities have developed preferences and classification systems, in which cultural cognitive processes are represented which encapsulate specific conceptions of nature, as well as cumulative learing, beliefs and customs that are part of specific communities and cultures (Luna-José and Rendon 2012). Luna-José and Rendon (2012) further manifest that the mentioned grouping includes life form and variety categories, as well as monotypical and polytypical names which allow the plants in an ecosystem to be classified. Furthermore, these processes permit the differentiation of wild, native, exotic, cultivated, naturalized, and adventitious (Castellano 2011; Pérez and Matiz-Guerra 2017) while also categorizing managed areas such as traditional and commercial poli-crops, monocrops, paddocks, and forests (Bautista et al. 2018), as well as gardens (Mendoza-García et al. 2011).

To Casas and Caballero (1995) Latin American rural populations base their subsistence in agriculture, particularly in terms of food, and only about $15 \%$ of ther diet is obtained through collection of wild species. This statement easily extrapolates to other anthropocentric use categories. Because of this, we might expect cultivated plants to have a greater cul- 
tural significance than do wild plants, particularly because the latter need only be harvested directly from spaces such as forests, while the former impies a productive process in which nature is transformed and resource availability is managed by controlling nutrients, humidity, light, temperature, competition, and depredation (Casas and Caballero 1995).

Considering this, farmers in general have maintained and adopted diverse strategies, combining modern and traditional agricultural varieties (Estupiñán-González et al. 2010; Kehoe et al. 2017), and they have preserved the goods and services that they provide (Nesper et al. 2018; Tscharntke et al. 2011). Among these, there have been studies on the relevance of agroforestry systems for the production of wood and timber (e.g. Brandt et al. 2013; Castillo et al. 2014); medicine (e.g. Bermúdez et al. 2005; Giraldo et al. 2009), and food security (e.g. Córdoba et al. 2019; De Beenhouwer et al. 2013). However, the rural world, traditional agriculture, and agroecosystems throughout the world are being subjected to quick transformation processes and varied demands, due mainly to the development of a technified agriculture (Grab et al. 2018; Pérez-Álvarez et al. 2018), to government policies, free trade agreements, poverty, migration of rural populations to urban areas, and other factors (Altieri and Nichols 2010). In this transition, agricultural systems are affected by complex interactions between social and ecological factors (Nkurunziza 2020), which has changed the access, use, and availability of natural resources. In turn, this has transformed rural territoriThe recognition of useful flora and the preference for certain plants by different social groups makes it possible to generate a critical starting point for the design of conservation actions within transformed areas, which could lead to greater interest and participation by local populations (Castellano 2011). Upon these scenarios, ethnobotany serves as a bridge between local knowledge and rural traditions associated to the use and management of vegetable species; the ethnobotanical heritage has an important role as an element of identity and a benchmark for local cultures (Pardo de Santayana and Gómez 2003). This knowledge continues to be a reliable and valuable source to learn about vegetation dynamics and it is the basis for the management of local resources (Wezel and Lykke 2006).

Thus, a culturally significant plant may be defined as a plant species that is desired, preferred or highly regarded in terms of affection by most members of a specific culture (Tardío and Pardo de Santayana 2008), which may also relate to ecological, cultural, and genetic factors that shape behavior and species selection according to adaptative memory and cultural affinity (da Silva et al. 2020). Moreover, the significance of a species can be explained by diverse factors such as the number of uses as per ethnobotanic category, availability, acces to the resource, or its origin (Rosero-Toro et al. 2018a). Therefore, ethnobotanists have begun to study local knowledge incorporating quantitative analyses, which make it possible to evaluate the relationship between biological and cultural diversity, as well as the relative significance of natural resources for a local population (Medeiros et al. 2011). To evaluate the cultural significance of diverse organisms (plants, animals and mushrooms) quantitatively, different indicators have been proposed. One such proposal is the Frequency of Mention, based on the premise that the more important an organism is for a community, the more likely it will be named in a free listing (García del Valle et al. 2015; Ruan-Soto 2020; Weller and Romney 1988). The elements which are mentioned most frequently are assumed to be of greater cultural significance to the studied population (Hilgert 2007; Thompson and Juan, 2006).

Over the last few decades, increased worldwide efforts have been made to recognize the cultural significance of plant species (e.g., Albuquerque et al. 2020; Cruz-Pérez et al. 2021; León-Merino et al. 2017; Mendoza et al. 2020); however, a deeper focus on agroforest systems, such as shade coffee plantations, is required. Shade coffee plantantions are deemed important refuges for biodiversity (De Beenhouwer et al. 2013) as they contain varied useful species which can be potentially commercialized (Martínez et al. 2007) and preserved. Consequently, local communities have developed preferences and classification systems, in which cultural cognitive processes are represented which encapsulate specific conceptions of nature, as well as cumulative learing, beliefs and customs that are part of specific communities and cultures (Luna-José and Rendon 2012). Luna-José and Rendon (2012) further manifest that the mentioned grouping includes life form and variety categories, as well as monotypical and polytypical names which allow the plants in an ecosystem to be classified. Furthermore, these processes permit the differentiation of wild, native, exotic, cultivated, naturalized, and adventitious (Castellano 2011; Pérez and Matiz-Guerra 2017) while also categorizing managed areas such as traditional and commercial poli-crops, monocrops, paddocks, and forests (Bautista et al. 2018), as well as gardens (Mendoza-García et al. 2011).

To Casas and Caballero (1995) Latin American rural populations base their subsistence in agriculture, particularly in terms of food, and only about $15 \%$ of ther diet is obtained through collection of wild species. This statement easily extrapolates to other anthropocentric use categories. Because of this, we might expect cultivated plants to have a greater cultural significance than do wild plants, particularly be- 
cause the latter need only be harvested directly from spaces such as forests, while the former impies a productive process in which nature is transformed and resource availability is managed by controlling nutrients, humidity, light, temperature, competition, and depredation (Casas and Caballero 1995).

Considering this, farmers in general have maintained and adopted diverse strategies, combining modern and traditional agricultural varieties (Estupiñán-González et al. 2010; Kehoe et al. 2017), and they have preserved the goods and services that they provide (Nesper et al. 2018; Tscharntke et al. 2011). Among these, there have been studies on the relevance of agroforestry systems for the production of wood and timber (e.g. Brandt et al. 2013; Castillo et al. 2014); medicine (e.g. Bermúdez et al. 2005; Giraldo et al. 2009), and food security (e.g. Córdoba et al. 2019; De Beenhouwer et al. 2013). However, the rural world, traditional agriculture, and agroecosystems throughout the world are being subjected to quick transformation processes and varied demands, due mainly to the development of a technified agriculture (Grab et al. 2018; Pérez-Álvarez et al. 2018), to government policies, free trade agreements, poverty, migration of rural populations to urban areas, and other factors (Altieri and Nichols 2010). In this transition, agricultural systems are affected by complex interactions between social and ecological factors (Nkurunziza 2020), which has changed the access, use, and availability of natural resources. In turn, this has transformed rural territories (Perfetti et al. 2013; Perfecto and Vandermeer 2015).

In Colombia, coffee is grown in approximately 590 municipalities (Gallego 2007). Most of the activity (around 96\%) is carried out by small producers in areas under 5 ha (Echavarría et al. 2015; FNC 2020), who are recognized by their high-quality standards, production and exportation of mild-flavored coffees, an aspect that is valued in international markets (FNC 2019). Despite the status of coffee as one the main elements for the country's economy (Cerquera and Orjuela 2015). Research in traditional coffee-producing regions has been focused on recognizing economic changes, the evolution and consolidation of coffee, as well as the loss of dynamism in the coffee-production sector (Aguilar 2003; Cano 2012). Likewise, there has been in-depth research on the role of the Coffee Cultural Landscape, World Heritage since 2011, has had for several sectors, such as tourism and agriculture (Mayorga 2015), and on the analysis of sociocultural variables for coffee collectors (Parada 2017); as well as on ecosystem services and biodiversity management and conservation (Armbrecht 2009; Cepeda-Valencia et al. 2014; Chait 2015; ManceraSanta 2019).

In Huila, research in coffee producing zones is scarce and often focused on the incidence of climate variation on the production of coffee (Pérez et al. 2016; Sánchez et al. 2017), coffee varietals (Gallego 2007), agronomic quality (Rodríguez et al. 2014), social trajectory and coffee production (Salcedo 2016), and floristic and ethnobotanic analysis (Rosero-Toro et al. 2018b). In spite of this, little is known about the culturally significant species in coffee planting communities and whether preferences favor cultivated species over wild ones, or whether preference is different between species from different managed spaces (such as orchards, forests, coffee plantantions, or others) used by coffee farmers.

The importance that management spaces have for coffee producing agriculturers is highlighted, considering that an average of $24 \%$ of the farms are dedicated to coffee cultivation, while the rest include forest land, grasslands, gardens, and other management spaces (Riveros et al. 2008). In this context, the following question was posed: How does the cultural significance of the plants used by a coffee growing community relate to the managed spaces ("coffee plantation", "forest", "garden", "orchard", "market") and their origin ("wild", "cultivated")? This study aims at knowing the relationship between culturally significant botanical species with the management spaces and their origin, testing the hypothesis that plants with the highest cultural significance will be those obtained from coffee plantation sites and of cultivated origin.es (Perfetti et al. 2013; Perfecto and Vandermeer 2015).

In Colombia, coffee is grown in approximately 590 municipalities (Gallego 2007). Most of the activity (around $96 \%$ ) is carried out by small producers in areas under 5 ha (Echavarría et al. 2015; FNC 2020), who are recognized by their high-quality standards, production and exportation of mild-flavored coffees, an aspect that is valued in international markets (FNC 2019). Despite the status of coffee as one the main elements for the country's economy (Cerquera and Orjuela 2015). Research in traditional coffee-producing regions has been focused on recognizing economic changes, the evolution and consolidation of coffee, as well as the loss of dynamism in the coffee-production sector (Aguilar 2003; Cano 2012). Likewise, there has been in-depth research on the role of the Coffee Cultural Landscape, World Heritage since 2011, has had for several sectors, such as tourism and agriculture (Mayorga 2015), and on the analysis of sociocultural variables for coffee collectors (Parada 2017); as well as on ecosystem services and biodiversity management and conservation (Armbrecht 2009; Cepeda-Valencia et al. 2014; Chait 2015; ManceraSanta 2019).

In Huila, research in coffee producing zones is scarce and often focused on the incidence of climate variation on the production of coffee (Pérez et al. 
2016; Sánchez et al. 2017), coffee varietals (Gallego 2007), agronomic quality (Rodríguez et al. 2014), social trajectory and coffee production (Salcedo 2016), and floristic and ethnobotanic analysis (Rosero-Toro et al. 2018b). In spite of this, little is known about the culturally significant species in coffee planting communities and whether preferences favor cultivated species over wild ones, or whether preference is different between species from different managed spaces (such as orchards, forests, coffee plantantions, or others) used by coffee farmers.

The importance that management spaces have for coffee producing agriculturers is highlighted, considering that an average of $24 \%$ of the farms are dedicated to coffee cultivation, while the rest include forest land, grasslands, gardens, and other management spaces (Riveros et al. 2008). In this context, the following question was posed: How does the cultural significance of the plants used by a coffee growing community relate to the managed spaces ("coffee plantation", "forest", "garden", "orchard", "market") and their origin ("wild", "cultivated")? This study aims at knowing the relationship between culturally significant botanical species with the management spaces and their origin, testing the hypothesis that plants with the highest cultural significance will be those obtained from coffee plantation sites and of cultivated origin.

\section{MATERIAL AND METHODS}

\section{Study area}

The study was carried out in the vereda (village) Las Delicias in the Acevedo municipality (Huila, Colombia), Colombia, which comprises an agroecosystem located in the biomes of a subhumid and humid pre-montane forest with an extension of 335.96 ha, it has a warm, very humid climate with temperatures oscillating annually between 12 and $24^{\circ} \mathrm{C}$; it has an altitudinal range between 1000 and 2000 m.a.s.l (Figure 1). According to the 2016-2019 Acevedo Municipal Development Plan, this vereda contains 70 households. Although no updated data about the population in this area is available, there is an estimated average of 100 inhabitants. This number fluctuates due to migration to other departments like Cauca and Nariño, migrants being mainly men who work as coffee pickers, leaving women in charge of the fincas. The community vereda Las Delicias has a coffeeproduction-based economy, but this is combined with corn, banana, casava, sugarcane, and shade trees production, which provide additional income as well as alimentary support for the community. At the municipality level, coffee production is the most relevant activity as they are among the most prolific producers of the Huila department, with around 9054 cultivated ha and 2000 families linked to this sector (Sánchez et al. 2017).

\section{Selection of participants}

Interviewees were selected based on different conditions: residing in the area for over 10 years, dedicated to agriculture, above 18 years of age, and with time availability to participate in the project. Following these requirements, we worked with 41 people: 33 women and 8 men, between 18 and 74 years old. Considering the selection criteria, we obtained a lower participation from men, which can be due to the activities they carry out outside of coffee production. However, this makes it evident that men and women engage in an activity exchange that allows the development of links and knowledge about the flora within the territory. Lastly, the community authorized the use of all data obtained through the proposed methodologies by previous, free, and informed consent (Cano-Contreras et al. 2016).

\section{Data collection}

To gather information, qualitative and quantitative variables were considered. To delve into the management spaces and the origin of the useful plants, the ethnographic method was used through techniques like semi-structured interviews, ethnobotanical walks (Guber 2001), and participant observation (Páramo 2008). The latter was carried out throughout a year of constant coexistence with the community, in which there was participation in activities such as coffee collection, sowing of plants for both orchards and gardens, and exchange of agricultural produce. This helped strengthen communication processes, as well as active participation, while providing insight on territorial recognition, interactions between the community and agroecosystems, management strategies and species classification.

Additionally, Ethnobotanical categories recognizing the classification systems and useful species in each category were established alongside the participants. It is noteworthy that a single species may be reported in more than one category, according to the uses cited by an interviewee.

To calculate the cultural significance (CS) we used the Frequency of Mention Index, in which significance is indicated by the number of times each plant is mentioned by the interviewees (Hernández et al. 2005; Tardío and Pardo de Santayana 2008). After this, the relative values of the frequency of mention data were subjected to a non-parametric U Mann-Whitney and Kruskal-Wallis test (Zar 1999), which was carried out using the Minitab 16 software, a choice of test set which was made because the data were not normally 
Rosero-Toro et al. 2021. Can cultural significance in plants be explained by domestication and usage spaces? A study case from a coffee producing community in Huila, Colombia

Ethnobio Conserv 10:28
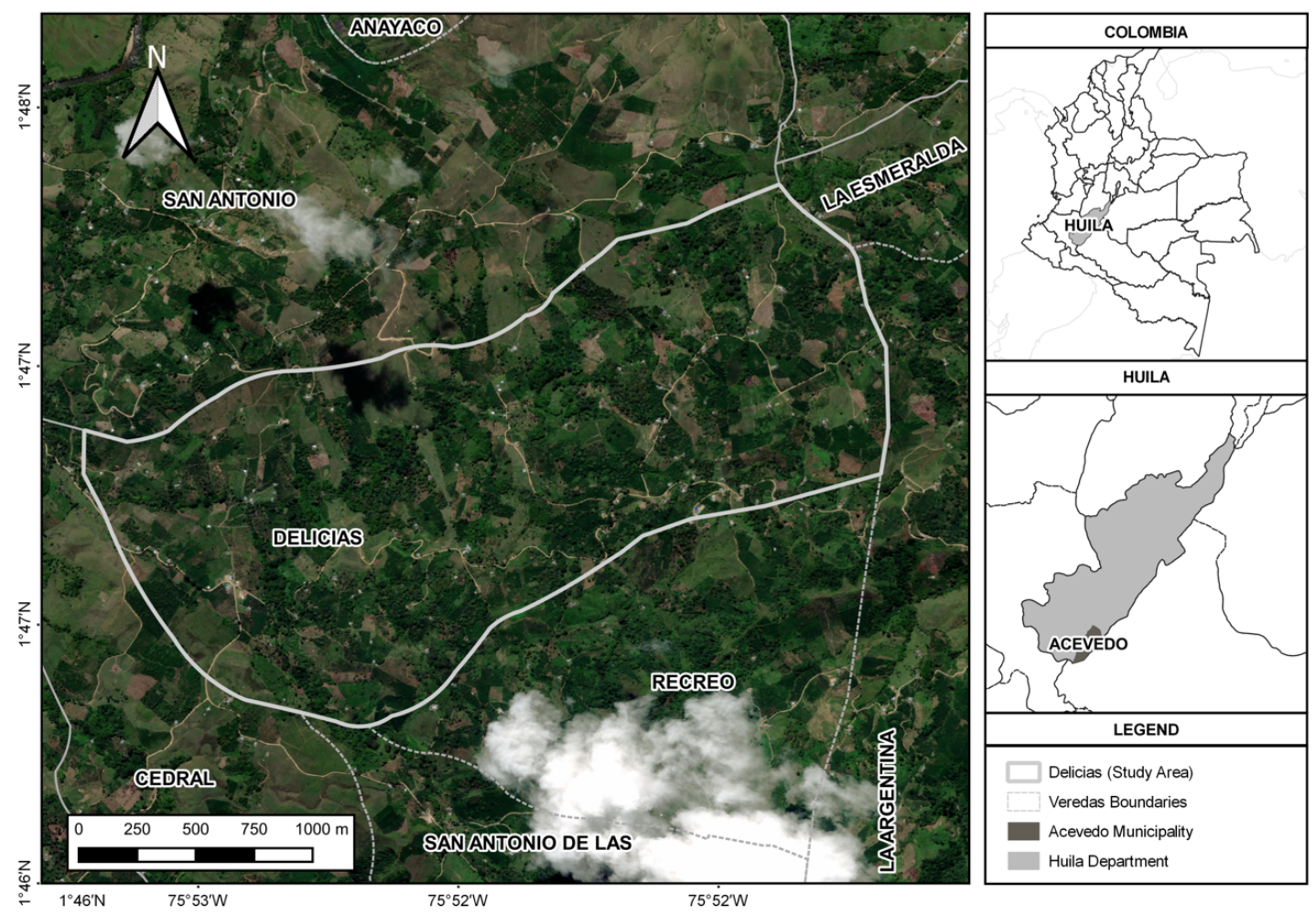

Figure 1. Location of vereda Las Delicias, Acevedo municipality (Huila, Colombia). Image by Trejo-Rangel (2020).

distributed. This helped determine whether significant differences exist between managed environments and the origin of useful plants. To carry out the CS analysis and the non-parametric tests, the data was extracted exclusively from interviews, while the analysis of botanical data incorporated all the species reported in both interviews and ethnobotanic walks.

Lastly, species determination was carried out using taxonomic keys and specialized databases. The TROPICOSRplatform and International Plant Names Index (IPNI) were used to confirm the current nomenclature of the scientific names, and the platform "Catálogo de plantas y líquenes de Colombia" (Catalogue of Plants and Lichens from Colombia) was consulted (Bernal et al. 2019) to know the origin of the species and their conservation status. The collected materials were deposited in the Universidad Surcolombiana Herbarium, SURCO (Neiva, Huila).

\section{RESULTS}

The community from vereda Las Delicias established five managed spaces of flora according to the composition, floristic distribution and access, called "Coffee plantation", "Garden", "Orchard", "Forest" and "Market", where the plants used as basic sup- port in farmers' households are concentrated. Additionally, it is in these spaces that the cultural tradition of the community converges, family members participate, and oral knowledge associated with plants is constructed. Because of this, speaking of managed spaces connects the ways in which coffee agro-ecosystems are perceived, community interactions with plants, and the forms of management, use and significance of useful flora. Taking into account the plants mentioned by space of use, the following was found: Coffee plantation with 91 plants (e.g. achira, aguanoso and cachingo), followed by Garden with 81 (e.g., francesina, clavelina and hortensia), Orchard with 41 (e.g. llantén, fríjol and espinaca), Market with 13 (e.g., remolacha, pepino and tomate) and Forest with 6 (e.g. algodón, roble and mariguano) (see Additional File1).

On the other hand, the community classified the flora into those that are considered "wild", that is, those that grow spontaneously in the ecosystem, and those that are "cultivated", which may be within managed spaces or can be acquired from crops external to the community. The cultural tradition, knowledge, and ecosystem management relative to each species were considered to classify useful flora. A link was established between the experience gained 
through oral tradition and contact with vegetation. Likewise, the community manifested the relevance of access and availability of a given species, which points to the generation of domestication processes for some wild species and underscores the relevance of vegetable species sown in the coffee agro-ecosystems, as well as species acquired in other spaces for the indispensable benefits they provide to the community. Therefore, for the wild category 50 plants were found, among them, guacamayo (Croton magdalenensis Müll. Arg.), guasco (Guatteria alta R.E.Fr.) and roble (Quercus humboldtii Bonpl.). As far as cultivated ones, 151 plants were reported, including aguacate (Persea americana Mill.), borrachero (Brugmansia suaveolens (Willd.) Bercht. \& J. Pres) and nacedero (Trichanthera gigantean (Humb. \& Bonpl.) Nees). Of the reported total, nine plants are found in both categories, such as achira (Canna indica L.), besitos (Impatiens hawkeri W. Bull and I. walleriana Gancho. F.) and cedro (Cedrela odorata L.) (see Additional File1).

When the managed spaces were associated to the relative frequency of mention, we observed significant differences in the CS for each of these spaces $(H=23.33 ; P=0.000)$. Their medians and $\mathrm{Z}$ vlaues indicate that this difference exists particularly between Orchards $(Z=3.04, M=0.2895)$ and Coffee plantations $(Z=1.56, M=0.1579)$. It became clear that plants from the coffee plantations have a higher degree of CS compared to plants from gardens and forests; this difference was significant. Meanwhile, it was not so when plants from the coffee plantation were compared with those from orchards and markets. Orchard plants were found to have a higher CS than plants from gardens and forests (Figure 2; Table 1).

When the cultivated and wild categories were compared, we found cultivated plants to have a higher cultural significance (CS) than wild plants $(\mathrm{U}=0.0032<0.05)$ as measured by their relative frequency of mention (Figure 3). The significance values are cited in table 1.

Meanwhile, the most important species according to the Frequency of Mention Index was café (Coffea arabica L.) (Relative mention frequency 1), followed by plátano (Musa balbisiana Colla) (0.95) and naranja (Citrus spp.) (0.92). The lowest reports corresponded to 29 species with a single citation, among them, anamú (Petiveria alliacea L.), bejuco de sapo (Cissus sicyoides L.) and salvajina (Tillandsia usneoides (L.) L.) (0.03) (see Additional File1).

With the semi-structured interviews, 192 plants were recorded by common name, however, considering the walk-in-the-forest interviews, 238 species were found. Fifteen of these had no local name even though they are used, while 46 of them have shared common names but are distinct taxonomic entities and may or may not be used similarly (see Additional File1). The most represented botanical families were Asteraceae (20 Genera, 23 species), Lamiaceae $(11,12)$, and Leguminosae $(8,11)$. The lowest representativity was shared among 35 Families which all had one genus and one species, among them are: Anacardiaceae, Bignoniaceae, Gesneriaceae, and Urticaceae (see Annex). Regarding growth habits, herbs were found to be the most widely represented (45\%), followed by trees (18\%) and shrubs (16\%) (Table 2). According to origin, 129 plants were classified as cultivated: 58 of these are native, 34 are native and cultivated, 4 are naturalized, 5 are naturalized and adventitious, 4 are cultivated and naturalized, 4 are adventitious, and 4 are endemic (see Additional File1). Regarding the state of conservation of the flora, 41 species are classified as "under minor concern" (e.g., C. magdalenensis, T. gigantea, and Zygia longifolia (Willd.) Britton \& Rose), 3 as "vulnerable" (Bactris gasipaes Kunth, Q. humboldtii, and Salvia rubescens Kunth), and 2 as "Endangered" (Cattleya trianae Linden \& Rchb.f. and C. odorata). This last pair is also reported in CITES, along with Opuntia ficus-indica (L.) Mill. and Mapinguari desvauxianus (Rchb.f.) Carnevali \& R.B. Singer.

With the participants help, ten ethnobotanical categories, defined below, were established: food (cultivated, purchased or wild species that are edible, including fruits); fuel (species used for timber or charcoal); spices (species employed to marinate or season other foods), construction (woody or non-woody species used to build pens, fences, supporting structures for homes or others); economic (species that generate income through their sale); fodder (species that are used as food for animals); medicinal (species employed in the prevention and treatment of diseases or illnesses that affect humans); ornamental (decorative species and those used in the decoration of indoor and outdoor spaces within households); shade (species used to cast shadow over coffee plants); and others (useful species that are not included in the categories above).

We found that the greatest representativeness by ethnobotanical category was for Medicinal plants, with 82 species mentioned, among which are: arracacha (Arracacia xanthorrhiza Bancr.), ruda (Ruta graveolens L.) and yerbagolpe (Pseudelephantopus spiralis (Less.) Cronquist). According to the origin of the medicinal plants, 55 plants were reported to be cultivated, reporting cidra (Sechium edule (Jacq.) Sw.), fennel (Foeniculum vulgare Mill.) and maracuyá (Passiflora edulis Sims); and 22 wild plants were found, finding bejuco de sapo (C. sicyoides), 


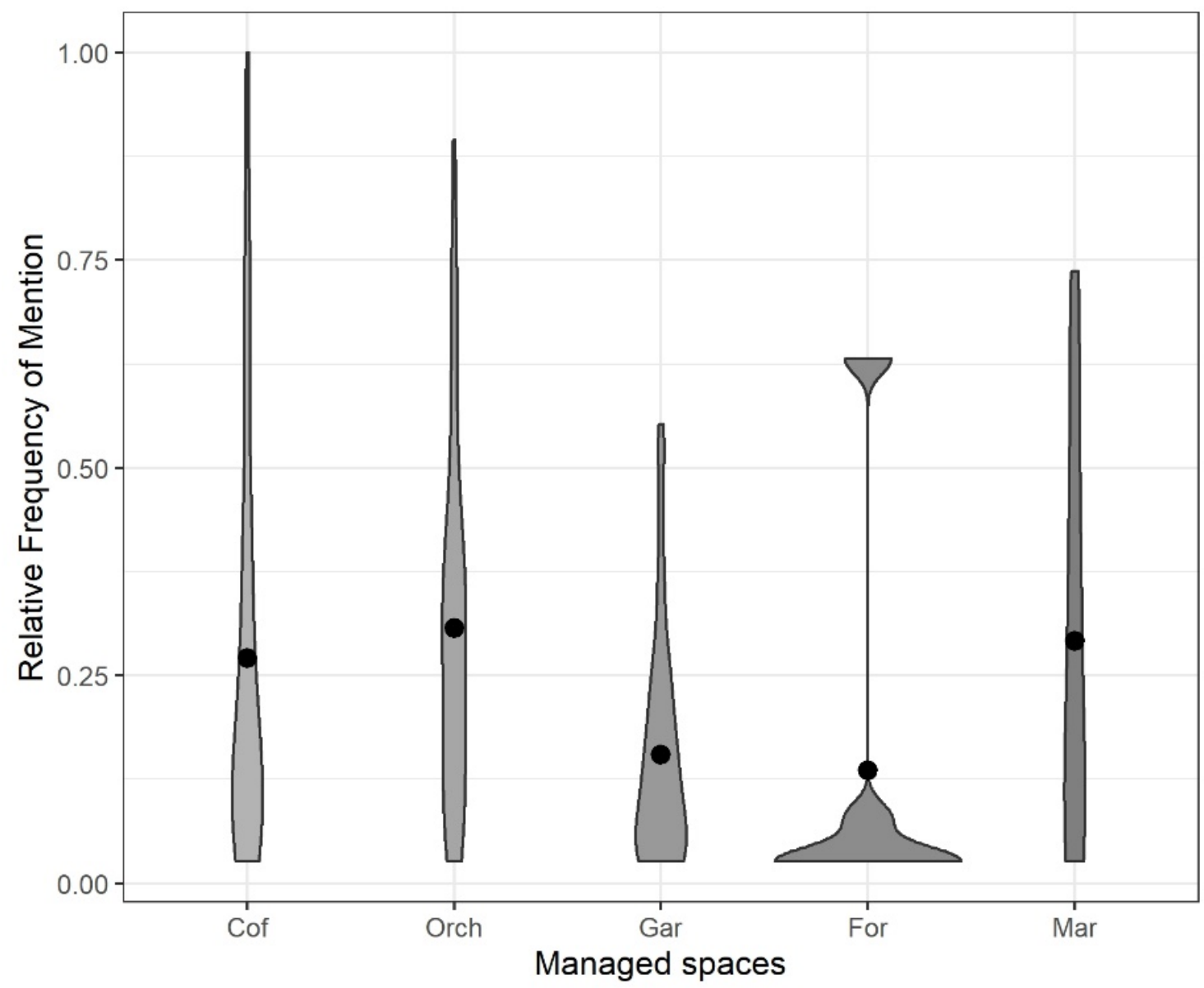

Figure 2. Cultural Singificance (CS) of the useful flora according to managed spaces: Coffee plantation (Cof), Forest (For), Garden (Gar), Orchard (Orch) and Market (Mar) in the vereda Las Delicias community (Acevedo, Huila). The $\mathrm{Y}$ axis is the Relative Frequency of Mention and the $\mathrm{X}$ axis are the managed spaces.

cordoncillo (Piper aduncum L.) and yarumo (Cecropia peltata L.).

The Ornamental category grouped 66 plants, being one of the categories with the largest number of exclusive species, that is, those reported to have a single use. Of these, only five correspond to wild plants, that is, caleña (Browallia Americana L.), campana (Ipomoea indica (Burm.) Merr.) and three orchids (Epidendrum catillus Rchb.f. \& Warsz., M. desvauxianus and Oncidium sp.). In the case of the Food category, 56 plants were mentioned, of which five are recognized as wild (e.g., C. indica, Rubus urticifolius Poir. and Vasconcellea pubescens A.DC.), but these are also found in coffee plantations. A similar situation is observed for the Fuel category, with 19 useful plants, and where seven wild species with distribution within the coffee plantations are reported, such as: yarumo (C. peltata), guasco (G. alta) and guacamayo (C. magdalenensis), and a single exclusive species for this category, the cedrillo (Ruagea glabra Triana \& Planch.).
In addition, this category shares nine species with the Construction category, including nacedero (T. gigantea) and votatumbo (Aegiphila truncate Moldenke). On the other hand, the Shade category presented 15 useful plants, of which eight correspond to cultivated (e.g. Pouteria caimito (Ruiz \& Pav.) Radlk, Psidium guajava L. and Inga spp.), seven are wild (e.g. Cordia alliodora (Ruiz \& Pav.) Oken, Guarea Guidonia (L.) Sleumer and Heliocarpus americanus L.), one species is in both categories $(C$. odorata $)$ and only one species has forest use (Brunellia comocladifolia Bonpl.).

For the flora of Economic use, 14 useful plants were reported, among them, the chontaduro (B. gasipaes), from which the fruit is commercialized, and the iraca (Carludovica palmate Ruiz \& Pav.), from which the leaves are sold for the production of the Suaceño hat, the two species have a wild origin. On the other hand, the Spice category registered 12 plants with this use, of which only ajo (Allium sativum L.) is purchased from the markets. Hierbabuena 


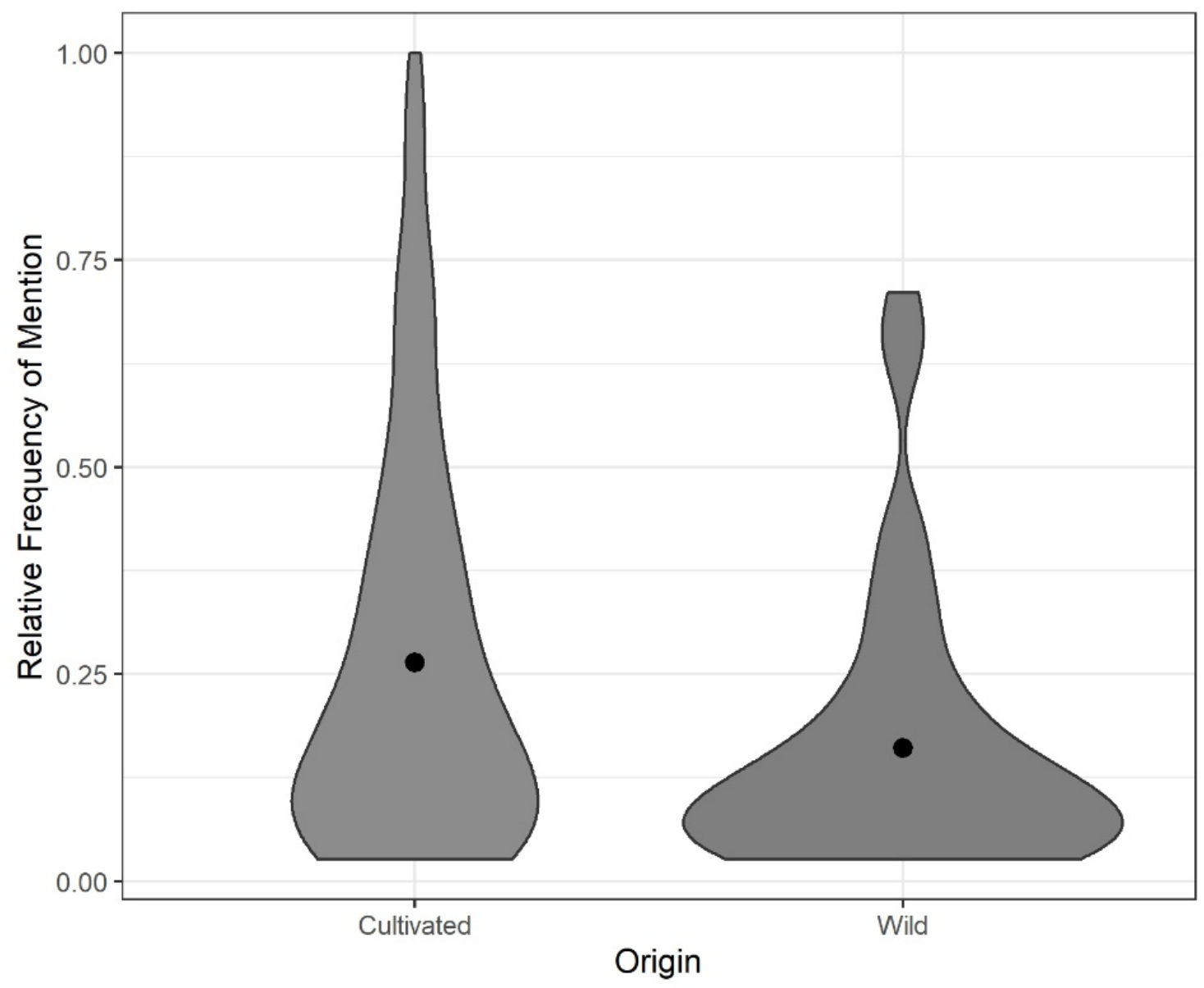

Figure 3. Relationship between the Cultural Significance (CS) of Cultivated versus Wild useful flora in the vereda Las Delicias community (Acevedo, Huila). The $\mathrm{Y}$ axis is the Relative Frequency of Mention and the $\mathrm{X}$ axis is the origin.

(Mentha spicata L.) can be found in the wild or be cultivated. Twelve plants were also reported for the Forage category, two wild: pacunga (Bidens pilosa L.) and bore (Xanthosoma sagittifolium (L.) Schott); the latter can also be found cultivated. Finally, 12 plants with other uses were reported, finding the $b i$ jao (Stromanthe jacquinii (Roem. \& Schult.) H.A. Kenn. \& Nicolson), from which the leaves are used to make tamales, the escoba (Sida rhombifolia L.) used for the manufacture of brooms, and the salvajina (T. usneoides) for the manufacture of Christmas decorations.

\section{DISCUSSION}

Managed spaces become natural reserves, cultural diversity conservation areas and the livelihood of rural families (Whitney et al. 2018). In turn, the variety of environments allows communities to obtain a greater number of goods and services, such as food, timber, firewood, in addition to contributing with species that provide pest control, regulation of temperature and soil moisture (Bukomeko et al. 2019). Regarding the reported managed spaces (coffee plantation, garden, orchard, forest, and market), we could observe coffee plantation species had a higher cultural significance than didplants from the gardens and forests. The cultural significance of this space may be explained by the diversity of wild and cultivated species within it, which collectively contribute to food sovereignty and rural ways of life (Altieri et al. 2012; Koohafkan and Altieri 2011). Furthermore, the sowing of various species and crop varieties stabilize long term output, promotes diversity, and optimizes economic resources (Altieri et al. 2012). The inclination or even preference to use managed spaces as the main source of resources has been previously documented from an ethnobiological point of view. Voeks (1996), for instance, described how people from the tropical rainforest in the state of Bahia, Brazil prefer managed (perturbed) areas because they are a significantly greater source of medicinal resources than are primary rainforest areas. 
Table 1. Significance values between the useful flora and the managed environment for the community of vereda Las Delicias (Huila, Colombia).

\begin{tabular}{ccc}
\hline \hline Space & Median & Mann-Whitney \\
\hline \hline Forest & 0.0263 & $\mathrm{U}=0.0567>0.05$ \\
Market & 0.2105 & \\
Garden & 0.1316 & $\mathrm{U}=0.0603>0.05$ \\
Market & 0.2105 & \\
\hline Garden & 0.1316 & $\mathrm{U}=0.1028>0.05$ \\
Forest & 0.0263 & \\
\hline Coffee plantation & 0.1579 & $\mathrm{U}=0.1224>0.05$ \\
Orchard & 0.2895 & \\
\hline Orchard & 0.2895 & $\mathrm{U}=0.7078>0.05$ \\
Market & 0.2105 & \\
\hline Coffee plantation & 0.1579 & $\mathrm{U}=0.7978>0.05$ \\
Market & 0.2105 & \\
\hline Coffee plantation & 0.1579 & $\mathrm{U}=0.0206<0.05$ \\
Forest & 0.0263 & \\
\hline Coffee plantation & 0.1579 & $\mathrm{U}=0.0030<0.05$ \\
Garden & 0.1316 & \\
\hline Orchard & 0.2895 & $\mathrm{U}=0.0000<0.05$ \\
Garden & 0.1316 & \\
\hline Orchard & 0.2895 & $\mathrm{U}=0.0145<0.05$ \\
Forest & 0.0263 & \\
\hline \hline
\end{tabular}

Table 2. Representation by growth habit of the flora used by the coffee-growing community Las Delicias (Huila, Colombia).

\begin{tabular}{lc}
\hline \hline Habit & Total \\
\hline \hline Herbaceous & 107 \\
Tree & 42 \\
Shrub & 39 \\
Climbing herb & 13 \\
Sub-shrub & 13 \\
Bush rosette & 8 \\
Climbing shrub & 5 \\
Epiphyte & 5 \\
Palm & 3 \\
Succulent shrub & 2 \\
Hemiparasitic shrub & 1 \\
\hline \hline
\end{tabular}

Despite there being a significant difference between managed areas (Coffee plantation and garden, coffee plantation and forest, orchard and garden, orchard and forest), these spaces are structured according to the species' access and availability, their precedence, growth habit, and cultural significance. The relevalnce of these spaces in creating opportunities for restoration and conservation, as well as improving the provision and regulation services of the agroecosystem (Leijster et al. 2021). Considering this, conservation strategies can be differentiated according to the structure and organization of the territory, for instance, a large portion of the flora used in coffee plantations and forests have a shrub or tree habit and are less readily available in orchards and gardens, because of which the use of woody species can be bolstered without affecting resource availability and meeting the agriculture's needs (Fernandes et al. 2014). Furthermore, cultural, ecological, social, and economic elements converge in areas such as orchards and gardens, generating an exclusive selection of species within (Trillo and Audisio 2018). Additionally, human-plant relationships are further reinforced with practices carried out in agro-forestal environments, since these are anthropogenic habitats relevant for the cultural services they provide to the local 
population (Hart et al. 2017).

For the study area, different forms of management and use of natural resources are evident, among them, a use of wild and cultivated vegetation within the farms. In this way, the hypothesis that cultivated plants have a higher cultural significe (151 species) than do wild species was supported, since they provide the benefits of quick access and being an efficient, safe and low-cost alternative (Jaramillo et al. 2014; Rosero-Toro et al. 2018a), and they have a higher diversity and usage versatility (Hart et al. 2017). Additionally, cultivated plants have been recorded to be addressed mainly in terms of their value as food, as they provide fruits and vegetables but are also ornamental (Magwede et al. 2019), y medicinales, which promotes the use of sown species in the vereda Las Delicias community.

Likewise, although the number of wild plants was lower, it is known that the domestication process originated from ethnobotanical knowledge, and there has been a significant progression of locally useful wild plants towards cultivation (Angulo et al. 2012; Leakey 2019). Species such as paico (Chenopodium ambrosioides L.), mejorana (Origanum majorana L.), poleo (Satureja brownie (Sw.) Briq.) and verbena (Verbena litoralis Kunth) have already been previously described for their medicinal value and for initially growing in wild environments, but they are increasingly being incorporated in the managed environments (Angulo et al. 2012). This transition allows rural communities to conserve greater diversity within agroforestry systems, generate surpluses that can be traded or exchanged, and provide economic stability by allowing other sources of income (Acevedo-Osorio and Martínez-Collazos 2016; Cerquera and Orjuela 2015; Turbay et al. 2014). Furthermore, the preference of wild or cultivated species will dependo $n$ the way in which local communities percieve the costs and benefits associated to the use of natural resources (Gama et al. 2018).

It was evident that coffee is the most important species by relating plants of cultural significance. Its cultivation at the national level has generated economic, social, and institutional development, and it has stabilized the country's economic growth (Cerquera and Orjuela 2015). In addition to this, the community has a cultural attachment to this crop that has been inherited for generations, throughout a constant struggle to defend their territory and their farming traditions. The importance of the coffee plant is manifested not only because of the resources it generates, but also because of the cultural richness that develops around it, converging with spaces in which families share and teach about agricultural spaces and methods. In addition to the above, it was evident that the plants with the highest frequency of mention correspond to those that grow in coffee plantations; a situation previously reported by Pascual-Mendoza et al. (2020) for a Zapotec community in the Northern Sierra of Oaxaca, Mexico. Furthermore, these authors indicated that production in coffee plantations is supplemented to satisfy the needs of their inhabitants.

We reconize that people recall relevant information for survival independently from their environment and culture, and that the ability to remember information is not exclusively linked to ancestral needs (Moura et al. 2020). Because of this, in order to understand the relationship between the cultural significance of useful flora with managed environments and origin, it is first necessary to know the social and cultural organization of each community. In this way, it was found that women fulfill very important roles by actively participating in the collection and caring of plants, as well as attention to cooking, while men are associated with soil preparation and maintenance of the crops, a situation that has been mentioned by several authors, including Krapovickas (2010), PascualMendoza (2018) and Rodríguez (2013). Participation and gender equality in rural development processes generate positive impacts, among them, it significantly increases productivity results in the agricultural sector (Córdoba et al. 2019). Additionally, it creates a balance between the traditional forms of cultivation and the new techniques of agriculture, where practices of shade-grown coffee have been implemented, new varieties have been integrated, and strategies that guarantee a greater production have been adapted to manage the crop (Figure 4).

The most important ethnobotanical category by number of plants accounted for corresponds to Medicinal, which constitutes an efficient, safe and therapeutic alternative and is often the only accessible and economic source of treatments that rural communities have (Bussmann and Sharon 2016; Fonnegra et al. 2013). In addition, the main diseases or ailments reported are associated with stomach pains, headaches, respiratory problems, fever, and nerve disorders, which have been widely cited in other studies (Campos-Saldaña 2018; Gross et al. 2019). On the other hand, the cultural significance of the ornate category reflects its role of providing enjoyment for people, in some cases in configurations combining ornamental and medicinal species (Mendoza-García et al. 2011). However, research focused on these managed areas both in rural and urban communities are scarce (Salas 2010) and the existing efforts tend to be part of general ethnobotany studies (Goddard et al. 2009; León-Merino et al. 2017). This overlooks the relevance of such spaces for the conservation of endangered species, as is the case of $C$. trianae, an endemic orchid which is cultivated in Colombia. Fur- 

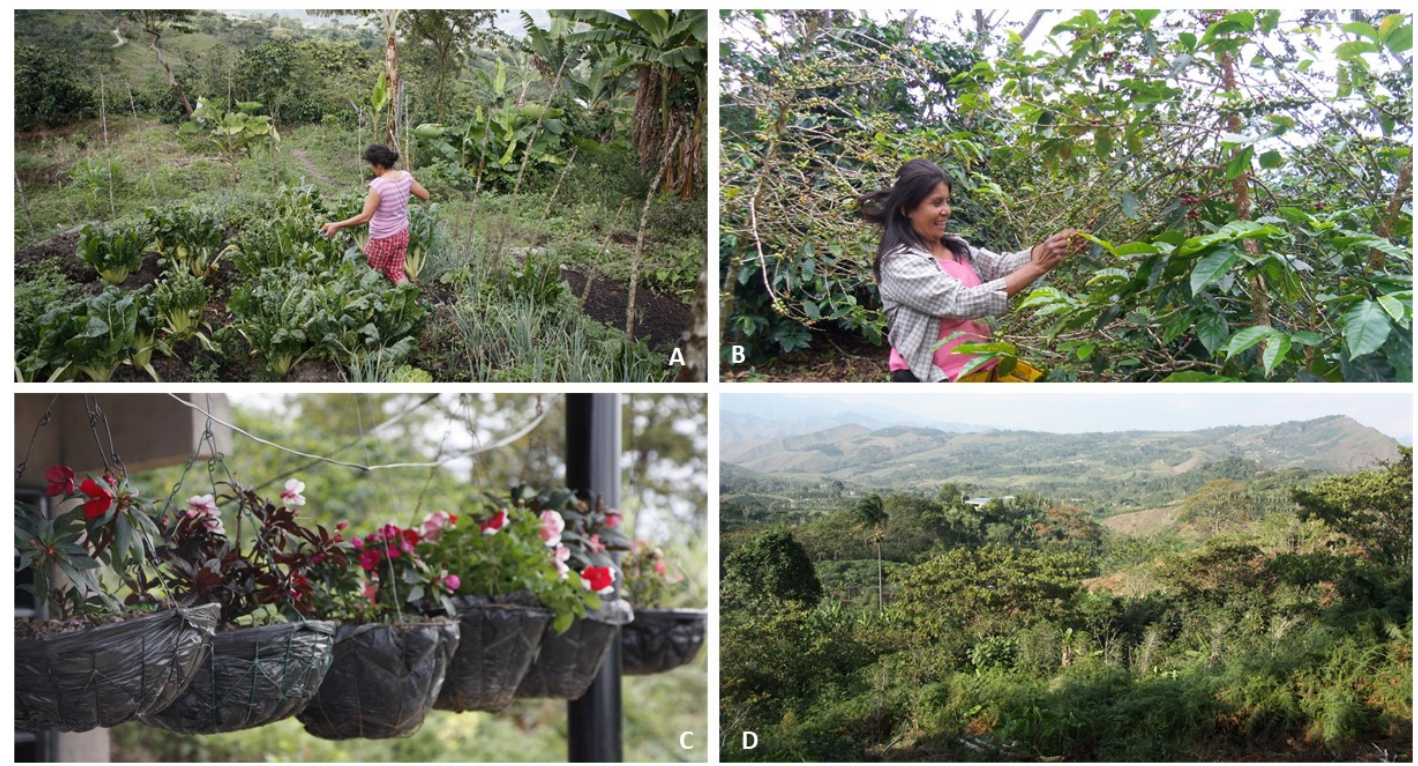

Figure 4. Management of the coffee system based on the managed environments A) Orchard, B) Coffee plantation, C) Garden, and D) Forest within the managed areas of the coffee-growing community of the vereda Las Delicias (Huila, Colombia).

thermore, species that are not necessarily endangered but are in risk of becoming so unless their commerce is strictly controlled, such as $M$. desvauxianus and O. ficus-indica, are evident in these spaces.

Finally, although the Food category did not report the highest number of plants, it does correspond to one of the most important ones because it is the main axis of the farmer's culture in this study area. Useful plants for this category contribute to the family's support, and in turn may have other additional uses. For example, some of the plants reported are also used for construction, medicine, firewood, fodder, and shade in coffee plantations (e.g., Castillo et al. 2019; Paredes-Flores et al. 2007). In addition, they provide economic support, either by selling their surplus, exchanging with other families or by consuming them, which means they are not purchased in the markets. Ultimately, it is not only about the agricultural technique, nor the conservation of biodiversity, but also about human culture and the rationality of a way of living and deciding what to eat and how to eat it, thus guaranteeing food sovereignty and security (Moreno-Calles et al. 2016).

\section{CONCLUSION}

The exposed results contribute to the recognition of the ethnobotanical processes and the relations between the community and their territory. The cultural significance of species was proved to be related to the managed spaces they inhabit, with higher significance in coffee plantation spaces than in gardens and forests. Coffee plantations are spaces in which the most important economic and family activities are carried out within rural communities, thus becoming the stages for rural knowledge dialogues and knowledge transmission. In this way, rural traditions play a vital role in the preservation of coffee ecosystems, which guarantee family subsistence and a diversification of spaces in which vegetable resources can be managed and become sources of economic income, generating processes that simultaneously allow managmente and protection for the natural resources of the region.

On the other hand, cultivated species appear to have a higher cultural significance than the wild species reported in this study, which makes evident the relevance of deep management of plants and how this is reflected in the differentiated relevance that people assign them. However, this is not to underestimate the uses that people give wild plants, as that they are increasingly incorporated into harvesting systems, generating management and domestication processes and increasing resilience from agroecosystems, especially from shade-grown coffee systems. This opens the possibility for a diversified supply of vegetable resources originating in different managed spaces that, together, hold the economy and the social and cultural reproduction of coffee producers in regions similar to our study site. Likewise, these spaces are recognized as centers of conservation of 
Rosero-Toro et al. 2021. Can cultural significance in plants be explained by domestication and usage spaces? A study case from a coffee producing community in Huila, Colombia

Ethnobio Conserv 10:28

plant and cultural diversity, where more than 50 native species of cultural significance are housed, and there are records of more than 40 species categorized in some category of conservation.

On the other hand, the species of greatest cultural importance was coffee ( $C$. arabica), due to the variety of its uses, as it is reported in the Medicinal, Food, Fuel and Economic categories. Likewise, the importance of coffee lies in the fact that it is part of the customary heritage of this community, allowing to strengthen in each generation the agricultural, environmental, and farming cooperation processes. Finally, although the farms are organized around this crop, the managed environments delimit the diversity of useful plants according to their use, access, and availability, with the aim of guaranteeing the subsistence of the households.

\section{ACKNOWLEDGEMENT}

We sincerely thank all residents of vereda Las Delicias for their hospitality and willingness to collaborate in the study. We also thank the SURCO Herbarium for the support in the curatorship and reception of the collected specimens. We would also like to thank Miguel Angel Trejo-Rangel, for the elaboration of the map of the study area; and Dikaryon Language Consultants for translation of this manuscript into English.

\section{DATA AVAILABILITY}

The data used to support the findings of this study are available from the corresponding author upon reasonable request.

\section{CONFLICT OF INTEREST}

The authors have no conflicts of interest to declare.

\section{CONTRIBUTION STATEMENT}

JHRT wrote early drafts of the research design and the manuscript and did the fieldwork.

HCDG, FRS and DSF reviewed and improved the proposal and the manuscript.

All authors read and approved the final manuscript.

\section{REFERENCES}

Acevedo-Osorio A, Martínez-Collazos J (Comps.) (2016) La agricultura familiar en Colombia. Estudios de caso desde la multifuncionalidad y su aporte a la paz. Bogotá: Ediciones Universidad
Cooperativa de Colombia - Corporación Universitaria Minuto de Dios - Agrosolidaria.

Aguilar LI (2003) Crisis del café y el desarrollo regional. Cuadernos de economía 22: 239-272.

Albuquerque UP, Brito AL, Nascimento ALB, Oliveira AFM, et al. (2020) Medicinal plants and animals of an important seasonal dry forest in Brazil. Ethnobiology \& Conservation conservación 9:8. doi: 10.15451/ec2020-03-9.08-1-53.

Altieri MA, Funes-Monzote FR, Petersen P (2012) Agroecologically efficient agricultural systems for smallholder farmers: contributions to food sovereignty. Agron. Sustain 32: 1-13.

Altieri MA, Nichols CI (2010) Agroecología: potenciando la agricultura campesina para revertir el hambre. Revista de economía crítica 10: 6274.

Amorozo MC, De Siqueira LC, Barreto CP, Cardoso IM (2014) Etnobotânica de Leguminosae entre agricultores agroecológicos na Floresta Atlântica, Araponga, Minas Gerais, Brasil. Rodriguésia 65(2): 539-554.

Angulo A, Rosero R, Gonzales M (2012) Estudio etnobotánico de las plantas medicinales utilizadas por los habitantes del corregimiento de Genoy, Municipio de Pasto, Colombia. Revista Universidad y Salud 14: 168-185.

Armbrecht I (2009) El papel de la matriz rural como conector entre reservas. En: Altieri MA (eds.). 2009. Vertientes del pensamiento agroecológico: fundamentos y aplicaciones. Sociedad Científica Latinoamericana de Agroecología (SOCLA), Medellín, Colombia. p. 343-362.

Bautista EA, Gutiérrez EV, Ordaz VM, Gutiérrez M, Cajuste L (2018) Sistemas agroforestales de café en Veracruz, México: identificación y cuantificación espacial usando SIG, percepción remota y conocimiento local. Terra Latinoamericana 36(3): 261-273.

Bermúdez A, Oliveira-Miranda MA, Velázquez D (2005) La investigación etnobotánica sobre plantas medicinales: una revisión de sus objetivos y enfoques actuales. Interciencia 30: 453459 .

Bernal R, Gradstein SR, Celis M (eds.) (2019) Catálogo de plantas y líquenes de Colombia. Instituto de Ciencias Naturales, Universidad Nacional de Colombia, Bogotá.

Brandt R, Mathez-Stiefel SL, Lachmuth S, Hensen I, Rist S (2013) Knowledge and valuation of Andean agroforestry species: the role of sex, age, 
Rosero-Toro et al. 2021. Can cultural significance in plants be explained by domestication and usage spaces? A study case from a coffee producing community in Huila, Colombia

Ethnobio Conserv 10:28

and migration among members of a rural community in Bolivia. Journal of ethnobiology and ethnomedicine 9: 83. doi: 10.1186/1746-4269-9-83.

Bukomeko H, Jassogne L, Tumwebaze SB, Eilu G, Vaast P (2019) Integrating local knowledge with tree diversity analyses to optimize on-farm tree species composition for ecosystem service delivery in coffee agroforestry systems of Uganda. Agroforestry Systems 93: 755-770.

Bussmann RW, Sharon D (2016) Plantas medicinales de los Andes y la Amazonía-La flora mágica y medicinal del Norte del Perú. Ethnobotany Research and Applications 15: 1-293.

Cabrera-Pérez S, Ochoa-Gaona S, Mariaca-Méndez R, González-Valdivia N, Guadarrama-Olivera M, Gama L (2013) Vulnerabilidad para el uso y distribución de especies leñosas desde la perspectiva local en la Reserva del Cañón del Usumacinta, Tabasco, México. Polibotánica 35: 143-172.

Campos-Saldaña RA, Solís-Vázquez OO, VelázquezNucamendi A, Cruz-Magdaleno LA, Cruz-Oliva DA, Vázquez-Gómez M, Rodríguez-Larramendi LA (2018) Saber etnobotánico, riqueza y valor de uso de plantas medicinales en Monterrey, Villa Corzo, Chiapas (México). Boletín latinoamericano y del Caribe de plantas medicinales y aromáticas 17: 350362 .

Cano CG, Vallejo C, Caicedo E, Amador JS, Tique EY (2012) El mercado mundial del café y su impacto en Colombia. Borradores de Economía. Banco de la República.

Cano-Contreras EJ, Medinaceli A, Sanabria OL, Argueta A (2016) Código de Ética para la Investigación etnobiológica en América Latina. Etnobiología 14 Supl 1: 1-32.

Casas A, Caballlero J (1995) Domesticación de plantas y origen de la agricultura en Mesoamérica. Ciencias 40: 36-45.

Castellano LI (2011) Conocimiento etnobotánico, patrones de uso y manejo de plantas útiles en la cuenca del río Cane-Iguaque (BoyacáColombia): una aproximación desde los sistemas de uso de la biodiversidad. Ambiente \& Sociedade 14: 45-75.

Castillo G, Ávila-Bello CH, López-Mata L, de León González F (2014) Structure and tree diversity in traditional popoluca coffee agroecosystems in the Los Tuxtlas Biosphere Reserve, Mexico. Interciencia 39: 608-619.

Castillo H, Albán Castillo J, Castañeda R (2019) Importancia cultural de la flora silvestre de la provincia de Cajabamba, Cajamarca, Perú. Arnaldoa 26: 1047-1074.

Cepeda-Valencia J, Gómez D, Nicholls C (2014) La estructura importa: abejas visitantes del café y estructura agroecológica principal (EAP) en cafetales. Revista Colombiana de Entomología 40: 241-250.

Cerquera ÓH, Orjuela Yacué CF (2015) El acompañamiento institucional en el desarrollo del sector cafetero colombiano. Revista Finanzas y Política Económica 7: 169-191. doi: 10.14718/revfinanzpolitecon.2015.7.1.9.

Chait G (2015) Café en Colombia: servicios ecosistémicos, conservación de la biodiversidad. En: Montagnini F, Somarriba E, Murgueitio E, Fassola H, Eibl B. (eds.) Sistemas Agroforestales. Funciones Productivas, Socioeconómicas y Ambientales. Serie técnica. Informe técnico 402. CATIE, Turrialba, Costa Rica. Editorial CIPAV, Cali, Colombia. p. 349-362.

Córdoba L, Gamboa H, Mosquera Y, Palacios Y, Salas MH, Ramos PA (2019) Productos forestales no maderables: uso y conocimiento de especies frutales silvestres comestibles del Chocó, Colombia. Cuadernos de Investigación UNED 11: 164-172.

Cruz-Pérez AL, Barrera-Ramos J, Bernal-Ramírez LA, Bravo-Avilez D, Rendón-Aguilar B (2021) Actualized inventory of medicinal plants used in traditional medicine in Oaxaca, Mexico. J Ethnobiology Ethnomedicine: 17, 7. doi: https://doi.org/10.1186/s13002-020-00431-y.

Da Silva RH, Ferreira Júnior WS, Moura JMB. et al. (2020) The Link Between Adaptive Memory and Cultural Attraction: New Insights for Evolutionary Ethnobiology. Evol Biol: 47, 273-284. doi: 10.1007/s11692-020-09516-8.

De Leijster V, Santos MJ, Wassen MW, et al. (2021) Ecosystem services trajectories in coffee agroforestry in Colombia over 40 years. Ecosystem Services 48: 101246.

Echavarría JJ, Esguerra P, McAllister D, Robayo CF (2015) Misión de estudios para la competitividad de la caficultura en Colombia. Resumen Ejecutivo. http://www.urosario.edu.co/ Mision-Cafetera/Archivos. 28 Jul. 2020.

Estupiñán-González AC, Jiménez-Escobar ND (2010) Uso de las plantas por grupos campesinos en la franja tropical del Parque Nacional Natural Paramillo (Córdoba, Colombia). Caldasia 21-38. 
Rosero-Toro et al. 2021. Can cultural significance in plants be explained by domestication and usage spaces? A study case from a coffee producing community in Huila, Colombia

Ethnobio Conserv 10:28

Federación Nacional de Cafeteros de Colombia, FNC (2019) Informe de Gestión 2019. Federación Nacional de Cafeteros de Colombia, Colombia.

Federación Nacional de Cafeteros de Colombia, FNC (2020) Diagnóstico de la asociatividad en el sector cafetero colombiano. Ensayos sobre Economía Cafetera 33: 9-36.

Fonnegra R, Villa J, Monsalve Z (2013) Plantas usadas como medicinales en el Altiplano del oriente Antioqueño - Colombia. Primera Edición. Medellín, Colombia.

Gallego JC (2007) Proceso de calificación y sello de calidad en relación con el origen, caso: Café de Colombia. Consultoría realizada para la FAO y el IICA en el marco del estudio conjunto sobre los productos de calidad vinculada al origen.

Gama, ADS, de Paula M, da Silva RRV, Ferreira WS, \& Medeiros PMD (2018) Exotic species as models to understand biocultural adaptation: Challenges to mainstream views of human-nature relations. PLoS One, 13(4), e0196091.

García del Valle, Y, Naranjo EJ, Caballero J, Martorell C, Ruan-Soto F, Enríquez PL (2015) Cultural significance of wild mammals in mayan and mestizo communities of the Lacandon Rainforest, Chiapas, Mexico. Journal of Ethnobiology and Ethnomedicine 11(36).

Giraldo D, Baquero E, Bermúdez A, Oliveira-Miranda MA (2009) Caracterización del comercio de plantas medicinales en los mercados populares de Caracas, Venezuela. Acta Botanica Venezuelica 267-301.

Goddard MA, Dougill AJ, Benton TG (2009) Scaling up from gardens: biodiversity conservation in urban environments. J. Trends Ecol. Evol. 30(10): $1-9$.

Grab H, Danforth B, Poveda K, Loeb G (2018) Landscape simplification reduces classical biological control and crop yield. Ecological Applications 28: 348-355.

Gross A, Dischkaln E, Müller LG, Kuze SM, Ritter MR (2019) Medicinal plants for the" nerves": a review of ethnobotanical studies carried out in South Brazil. Acta Botanica Brasilica 33: 269-282.

Guber R (2001) La etnografía: método, campo y reflexividad. Bogotá: Grupo editorial Norma.

Hart G, Gaoue OG, de la Torre L, Navarrete H, Muriel P, Macía MJ, Balslev H, León-Yánez S, Jørgensen P, \& Duffy DC. (2017) Availability, diversification and versatility explain human selection of introduced plants in Ecuadorian traditional medicine. PloS One, 12(9), e0184369.

Hernández T, Canales M, Caballero J, Durán Á, Lira R. (2005) Análisis cuantitativo del conocimiento tradicional sobre plantas utilizadas para el tratamiento de enfermedades gastrointestinales en Zapotitlán de las Salinas, Puebla, México. Interciencia 30: 529-535.

Hilgert N (2007) La Etnobotánica como herramienta para el estudio de los sistemas de clasificación tradicionales. En: Contreras-Ramos A, Cuevas C, Cardona C, Goyenenchea I, Iturbe U (eds.) La Sistemática, base para el conocimiento de la biodiversidad. Universidad Autónoma del Estado de Hidalgo. Pachuca, México. Pp. 103-112.

Jaramillo MA, Castro M, Ruiz-Zapata T, Lastres M, Torrecilla P, Lapp M, Hernández-Chong L, Muñoz D (2014) Estudio etnobotánico de plantas medicinales en la comunidad campesina de Pelelojo, municipio Urdaneta, estado Aragua, Venezuela. Ernstia 24: 85-110.

Kehoe L, Romero-Muñoz A, Polaina E, Estes L, Kreft H, Kuemmerle T (2017) Biodiversity at risk under future cropland expansion and intensification. Nature Ecology \& Evolution 1: 1129-1135.

Koohafkan P, Altieri MA (2011) Globally Important Agricultural Heritage Systems. A Legacy for the Future. Organización de las Naciones Unidas para la Agricultura y la Alimentación.

Krapovickas A (2010) La domesticación y el origen de la agricultura. Bonplandia 19: 193-199.

Leakey RR (2019) From ethnobotany to mainstream agriculture: socially modified Cinderella species capturing 'trade-ons' for 'land maxing'. Planta 250: 949-970.

León-Merino A, Rivera-Peña R, Hernández-Juárez M, Sangerman-Jarquín DM, Jiménez-Sánchez L, Valtierra-Pacheco E (2017) Aprovechamiento de productos forestales no maderables en la comunidad Pensamiento Liberal Mexicano, Oaxaca. Revista mexicana de ciencias agrícolas 8(18): 3725-3738.

Luna-José AL, Rendón B (2012) Traditional knowledge among Zapotecs of Sierra Madre Del Sur, Oaxaca. Does it represent a base for plant resources management and conservation? J Ethnobiology Ethnomedicine 8(24). doi: 10.1186/17464269-8-24.

Magwede K, Van Wyk BE, \& Van Wyk AE (2019) An inventory of Vhavenda useful plants. 
Rosero-Toro et al. 2021. Can cultural significance in plants be explained by domestication and usage spaces? A study case from a coffee producing community in Huila, Colombia

Ethnobio Conserv 10:28

South African Journal of Botany, 122, 57-89. doi: j.sajb.2017.12.013

Mancera-Santa JC (2019) Importancia ecológica y manejo ambiental en arreglos agroforestales de cafetales de Risaralda-Colombia. MSc Thesis, Universidad Tecnológica de Pereira.

Martínez MÁ, Evangelista V, Basurto F, Mendoza M, Cruz-Rivas A (2007) Flora útil de los cafetales en la Sierra Norte de Puebla, México. Revista Mexicana De Biodiversidad 78: 15-40.

Mayorga DA (2015) Paisaje Cultural Cafetero, Patrimonio de la Humanidad. La cuestión del discurso patrimonial en contraste con el paisaje de la caficultura. Territorios 32: 35-59.

Medeiros MFT, Silva OS, Albuquerque UP (2011) Quantification in ethnobotanical research: an overview of indices used from 1995 to 2009. Sitientibus série Ciências Biológicas 11: 211-230.

Mendoza A, Silva M, Castro-Ramírez AE (2020) Etnobotánica medicinal de comunidades Nuu Savi de la Montaña de Guerrero, México. Etnobiología 18(2): 78-94.

Mendoza-García R, Pérez-Vázquez A, GarcíaAlbarado JC, García-Pérez E, López-Collado J (2011) Uso y manejo de plantas ornamentales y medicinales en espacios urbanos, suburbanos y rurales. Revista mexicana de ciencias agrícolas 2(3): 525-538.

Moreno-Calles AI, Casas A, Rivero-Romero AD, Romero-Bautista YA, Rangel-Landa S, Fisher-Ortíz RA, Alvarado-Ramos F, Vallejo-Ramos M, SantosFita D (2016) Ethnoagroforestry: integration of biocultural diversity for food sovereignty in Mexico. Journal of ethnobiology and ethnomedicine 12: 1-21. doi: 10.1186/s13002-016-01276.

Moura JMB, da Silva RH, Ferreira Júnior W, da Silva TC, Albuquerque UP (2020) Theoretical Insights of Evolutionary Psychology: New Opportunities for Studies in Evolutionary Ethnobiology. Evol Biol 47: 6-17. doi: 10.1007/s11692-020-09491-0.

Nesper M, Kueffer C, Krishnan S, Kushalappa CG, Ghazoul J (2018) Simplification of shade tree diversity reduces nutrient cycling resilience in coffee agroforestry. Journal of applied ecology 56: 119-131.

Nkurunziza L, Watson CA, Öborn I, Smith HG, Bergkvist G, Bengtsson J (2020) Socio-ecological factors determine crop performance in agricul- tural systems. Scientific Reports 10: 1-12.

Parada PJ (2017) Práctica social y cultural del campesinado cafetero en cuatro municipios de Caldas (Colombia). Revista Colombiana de Sociología 40: 193-212.

Páramo P (2008) La investigación en las ciencias sociales. Técnicas de recolección de información. Universidad Piloto de Colombia. Segunda edición. Bogotá D.C.

Pardo de Santayana M, Gómez E (2003) Etnobotánica: aprovechamiento tradicional de plantas y patrimonio cultural. Anales Jardín Botánico de Madrid 60: 171-182.

Paredes-Flores M, Lira Saade R, Dávila Aranda PD (2007) Estudio etnobotánico de Zapotitlán Salinas, Puebla. Acta Botánica Mexicana 79: 13-61.

Pascual-Mendoza S (2018) Conocimiento tradicional y valor de uso de plantas de agroecosistemas en Las Delicias, Juquila Vijanos, Oaxaca. MSc Thesis, Instituto Politécnico Nacional, Oaxaca, México.

Pascual-Mendoza S, Manzanero-Medina GI, SaynesVásquez A, Vásquez-Dávila MA (2020) Agroforestry systems of a Zapotec community in the Northern Sierra of Oaxaca, Mexico. Botanical Sciences 98: 128-144.

Pérez D, Matiz-Guerra LC (2017) Use of plants by farming communities in rural areas of Bogotá DC, Colombia. Caldasia: 39(1), 68-78.

Pérez EP, Ramírez Builes VH, Peña Quiñones AJ (2016) Variabilidad espacial y temporal de la temperatura del aire en la zona cafetera colombiana. Investigaciones geográficas 89: 23-40.

Pérez-Alvarez R, Nault BA, Poveda K (2018) Contrasting effects of landscape composition on crop yield mediated by specialist herbivores. Ecological Applications 28: 842-853.

Perfecto I, Vandermeer J (2015) Coffee agroecology: a new approach to understanding agricultural biodiversity, ecosystem services and sustainable development. New York, Routledge. Perfetti JJ, Balcázar A, Hernández A, Leibovich J

(2013) Políticas para el desarrollo de la agricultura en Colombia. Sociedad de agricultores de Colombia (SAC) y Fedesarrollo. Primera edición. Bogotá, D.C.

Plan de Desarrollo Municipal de Acevedo 2016 2019. Llego el cambio. Caminos de Paz y Competitividad. https://cpd.blob.core.windows.net/ test1/68575planDesarrollo.pdf. 28 Jul. 2020. 
Riveros H, Vandecandelaere E, Tartanac F, Ruiz C, Pancorbo G (2008) Calidad de los alimentos vinculada al origen y las tradiciones en América Latina: Estudios de casos (No. IICA 664.07 C153) FAO, Roma (Italia) IICA, San José, Costa Rica.

Rodríguez E, Vega G, Suárez J (2014) Fuentes de variación que tienen efecto sobre los atributos sensoriales de taza en sistemas agroforestales de café (Coffea arabica) en el sur de Colombia. Revista Sennova 1: 64-77.

Rodríguez LM (2013) Mujeres cafeteras y los cambios de su rol tradicional. Sociedad y economía 24: 71-94.

Rosero-Toro JH, Gómez H. D, Santos-Fita D (2018a) Plantas utilizadas en una comunidad cafetera de Acevedo, Huila: catálogo etnobotánico. Neiva, Editorial Universidad Surcolombiana.

Rosero-Toro JH, Romero-Duque LP, Santos-Fita D, Ruan-Soto F (2018b) Cultural significance of the flora of a tropical dry forest in the Doche vereda (Villavieja, Huila, Colombia). Journal of ethnobiology and ethnomedicine 14: 1-16. doi: 10.1186/s13002-018-0220-0.

Ruan-Soto F (2020) Highly cultural signicant edible and toxic mushrooms among the Tseltal from the Highlands of Chiapas, Mexico. Ethnobiology and Conservation 9(32). doi: 10.15451/ec2020-08-9.32-1-20.

Salas SA (2010) De la ciudad al campo: proceso de cambio y apropiación del territorio rural en municipio de México. Revista de Planteamiento Territorial y Urbanismos Iberoamericana 14: 10-27.

Salcedo C (2016) Estrategias familiares, trabajo y orígenes de pequeños productores cafeteros en el Huila, Colombia. Ciencia Política 11: 161190 .

Sánchez V, Avendaño Y, Gaviria A, Gómez C (2017) Cambio climático y café (Coffea arabica) en Acevedo, Huila: una lectura desde sus cultivadores. I $+D$ Revista de Investigaciones 12: 59-69. doi: 10.33304/revinv.v12n2-2018006.

Tardío J, Pardo de Santayana M (2008) Cultural importance indices: a comparative analysis based on the useful wild plants of Southern Cantabria (Northern Spain). Economic Botany 62: 24-39.

Thompson E, Juan Z (2006) Comparative cultural salience: Measuring using free list data. Field Methods 18(4): 398-412.

Trillo C, Audisio C (2018) Las plantas medicinales de los huertos de pobladores de diferente tradición cultural en Bosques Chaqueños de Córdoba, Argentina. Boletín Latinoamericano y del Caribe de plantas medicinales y aromáticas 17: 104-119.

Tscharntke T, Clough Y, Bhagwat SA, Buchori D, Faust H, Hertel D, ... Scherber C (2011) Multifunctional shade-tree management in tropical agroforestry landscapes-a review. Journal of Applied Ecology 48: 619-629.

Turbay S, Nates B, Jaramillo F, Vélez JJ, Ocampo OL (2014) Adaptación a la variabilidad climática entre los caficultores de las cuencas de los ríos Porce y Chinchiná, Colombia. Investigaciones Geográficas, Boletín del Instituto de Geografía 85: 95112.

Voeks RA (1996) Tropical Forest Healers and Habitat Preference. Economic Botany 50(4): 381400.

Weller SC, Romney AK (1988) Systematic data collection. Newbury Park: Sage Publications.

Wezel A, Lykke AM (2006) Woody vegetation change in Sahelian West Africa: evidence from local knowledge. Environment, Development and Sustainability 8: 553-567.

Whitney CW, Bahati J, Gebauer J (2018) Ethnobotany and agrobiodiversity: Valuation of plants in the homegardens of southwestern Uganda. Ethnobiology Letters 9: 90-100. doi: 10.14237/ebl.9.2.2018.503.

Zar JH (1999) Biostatistical analysis. Pearson Education India.

Received: 15 April 2021

Accepted: 13 June 2021

Published: 28 June 2021 


\section{Additional Files}

\begin{tabular}{|c|c|c|c|c|c|c|}
\hline $\begin{array}{l}\text { Common name: } \\
\text { Spanish } \\
\text { (English if available!) }\end{array}$ & Scientific name & $\begin{array}{l}\text { Ethnobotanical } \\
\text { categories }\end{array}$ & $\begin{array}{l}\text { Management } \\
\text { space }\end{array}$ & $\begin{array}{l}\text { Origin from } \\
\text { an emic } \\
\text { perspective }\end{array}$ & $\begin{array}{l}\text { Origin from } \\
\text { an etic } \\
\text { perspective }\end{array}$ & $\begin{array}{l}\text { Relative } \\
\text { frequency } \\
\text { of mention }\end{array}$ \\
\hline $\begin{array}{l}\text { Acelga } \\
\text { (chard) }\end{array}$ & $\begin{array}{l}\text { Beta vulgaris 'cicla' } \mathrm{L} \text {. } \\
\text { (Amaranthaceae) }\end{array}$ & Foo; Eco & Orch; Mar & Cultivated & Cultivated & 395 \\
\hline $\begin{array}{l}\text { Achira } \\
\text { (purple arrowroot) }\end{array}$ & $\begin{array}{l}\text { Canna indica L. * } \\
\text { (Cannaceae) }\end{array}$ & Foo; Orn & Cof; Orch & Cultivated, wild & $\begin{array}{l}\text { Native and } \\
\text { cultivated }\end{array}$ & 132 \\
\hline Achote & $\begin{array}{l}\text { Bixa orellana } \mathrm{L} \text {. } \\
\text { (Bixaceae) (Lauraceae) }\end{array}$ & Spi & Cof; Gar & Cultivated & $\begin{array}{l}\text { Native and } \\
\text { cultivated }\end{array}$ & 184 \\
\hline $\begin{array}{l}\text { Aguacate } \\
\text { (avocado) }\end{array}$ & $\begin{array}{l}\text { Persea americana Mill. } \\
\text { (Lauraceae) }\end{array}$ & Foo; Med & Cof; & Cultivated & Cultivated & 289 \\
\hline Aguanoso & $\begin{array}{l}\text { Isertial laevis (Triana) B.M. Boom } \\
\text { (Rubiaceae) }\end{array}$ & Fue; Sha & Cof; & Wild & Native & 79 \\
\hline $\begin{array}{l}\text { Aji } \\
\text { (pepper) }\end{array}$ & $\begin{array}{l}\text { Capsicum annuum L.* } \\
\text { Capsicum frutescens } \mathrm{L} . * \\
\text { (Solanaceae) }\end{array}$ & Spi; Med & Cof; Orch; Gar & Cultivated & $\begin{array}{l}\text { Native and } \\
\text { cultivated }\end{array}$ & 158 \\
\hline $\begin{array}{l}\text { Ajo } \\
\text { (garlic) }\end{array}$ & $\begin{array}{l}\text { Allium sativim } \mathrm{L} . \\
\text { (Amaryllidaceae) }\end{array}$ & Spi; Med & Mar & Cultivated & Cultivated & 605 \\
\hline $\begin{array}{l}\begin{array}{l}\text { Albahaca } \\
\text { (basil) }\end{array} \\
\text { (a) }\end{array}$ & $\begin{array}{l}\text { Ocimum basilicum } \mathrm{L} . \\
\text { (Lamiaceae) }\end{array}$ & Spi; Med & Orch & Cultivated & Cultivated & 211 \\
\hline $\begin{array}{l}\text { Algodón } \\
\text { (cotton) }\end{array}$ & $\begin{array}{l}\text { Hasseltia sp. } \\
\text { (Salicaceae) }\end{array}$ & Med; Con & Cof; For & Wild & Native & 26 \\
\hline $\begin{array}{l}\text { Altamisa } \\
\text { (peruvian ragweed) }\end{array}$ & $\begin{array}{l}\text { Ambrosia peruviana Willd. * } \\
\text { (Asteraceae) }\end{array}$ & Med & Cof; Gar & Cultivated, wild & Native & 132 \\
\hline $\begin{array}{l}\text { Alverja } \\
\text { (pea) }\end{array}$ & $\begin{array}{l}\text { Pisum sativum } \mathrm{L} \text {. } \\
\text { (Fabaceae) }\end{array}$ & Foo & Orch & Cultivated & Cultivated & 342 \\
\hline $\begin{array}{l}\text { Amaranto } \\
\text { (bloodleaf) }\end{array}$ & $\begin{array}{l}\text { Iresine herbstii Hook. } \\
\text { (Amaranthaceae) }\end{array}$ & Med; Orn & Gar & Cultivated & Cultivated & 132 \\
\hline $\begin{array}{l}\text { Anamú } \\
\text { (guinea henweed) }\end{array}$ & $\begin{array}{l}\text { Petiveria alliacea } \mathrm{L} . \\
\text { (Petiveriaceae) }\end{array}$ & Med & Cof; & Wild & $\begin{array}{l}\text { Native and } \\
\text { cultivated }\end{array}$ & 26 \\
\hline Ángel caído & $\begin{array}{l}\text { Begonia minor Jacq. } \\
\text { (Begoniaceae) }\end{array}$ & Orn & Gar & Cultivated & Cultivated & 158 \\
\hline $\begin{array}{l}\text { Apio } \\
\text { (celery) }\end{array}$ & $\begin{array}{l}\text { Apium graveolens } \mathrm{L} . \\
\text { (Apiaceae) }\end{array}$ & Foo; Med & Orch & Cultivated & Cultivated & 263 \\
\hline $\begin{array}{l}\text { Arañita } \\
\text { (spider flower) }\end{array}$ & $\begin{array}{l}\text { Cleome spinosa Jacq. * } \\
\text { (Cleomaceae) }\end{array}$ & Orn & Gar & Cultivated & Native & 26 \\
\hline Arazá & $\begin{array}{l}\text { Eugenia stipitata McVaugh } \\
\text { (Myrtaceae) }\end{array}$ & Food & Cof, Gar & Cultivated & $\begin{array}{l}\text { Native and } \\
\text { cultivated }\end{array}$ & 26 \\
\hline $\begin{array}{l}\text { Arbol de navidad } \\
\text { (winter chery; } \\
\text { poisonous gooseberry) }\end{array}$ & $\begin{array}{l}\text { Solanum pseudocapsicum L. } \\
\text { (Solanaceae) }\end{array}$ & Orn & Gar & Cultivated & $\begin{array}{l}\text { Native and } \\
\text { cultivated }\end{array}$ & 26 \\
\hline Arracacha & $\begin{array}{l}\text { Arracacia xanthorrhiza Bancr } \\
\text { (Apiaceae) }\end{array}$ & Foo; Med; Eco & Cof; Orch & Cultivated & $\begin{array}{l}\text { Native and } \\
\text { cultivated }\end{array}$ & 368 \\
\hline $\begin{array}{l}\text { Arroz } \\
\text { (rice) }\end{array}$ & $\begin{array}{l}\text { Oryza sativa } \mathrm{L} . \\
\text { (Poaceae) }\end{array}$ & Foo & Mar & Cultivated & Cultivated & 368 \\
\hline $\begin{array}{l}\text { Azucena } \\
\text { (amaryllis; } \\
\text { peruvian lilly) }\end{array}$ & $\begin{array}{l}\text { Fippeastrum sp. Alstroemeria spp. } \\
\text { (Alstroemeriaceae) }\end{array}$ & Orn & Gar & Cultivated & $\begin{array}{l}\text { Native; } \\
\text { Cultivated }\end{array}$ & 368 \\
\hline Balso o Cadillo & $\begin{array}{l}\text { Heliocarpus americanus } \mathrm{L} \text {. } \\
\text { (Malvaceae) }\end{array}$ & Fue; Const; Sha & Cof; & Wild & Native & 158 \\
\hline $\begin{array}{l}\text { Banano } \\
\text { (banana) }\end{array}$ & $\begin{array}{l}\text { Musa } \times \text { paradisiaca } \mathrm{L} \\
\text { (Musaceae) }\end{array}$ & Foo & Cof & Cultivated & Cultivated & 368 \\
\hline $\begin{array}{l}\text { Begonia } \\
\text { (begonia, } \\
\text { waxy begonia, } \\
\text { gloxinia) }\end{array}$ & $\begin{array}{l}\text { Begonia } \times \text { tuberhybrida Voss } \\
\text { Begonia cucullata Willd.) } \\
\text { Begoniaceae) } \\
\text { Sinningia speciosa (Lodd.) Hiern } \\
\text { (Gesneriaceae) }\end{array}$ & Orn & Gar & Cultivated & Cultivated & 237 \\
\hline $\begin{array}{l}\text { Bejuco de sapo } \\
\text { (princess vine) }\end{array}$ & $\begin{array}{l}\text { Cissus verticillata } \\
\text { (L.) Nicolson \& C.E.Jarvis* } \\
\text { (Vitaceae) }\end{array}$ & Med & Cof & Wild & Native & 26 \\
\hline Besitos & $\begin{array}{l}\text { Impatiens haukeri W. Bull } \\
\text { Impatiens walleriana Hook. f. } \\
\text { (Balsaminaceae) }\end{array}$ & Orn & Cof; Gar & Cultivated; Wild & $\begin{array}{l}\text { Cultivated and } \\
\text { naturalized }\end{array}$ & 263 \\
\hline Bijao & $\begin{array}{l}\text { Stromanthe jacquinii } \\
\text { (Roem. \& Schult.) H. Kenn. \& Nicolson* } \\
\text { (Marantaceae) }\end{array}$ & Oth & Cof & Wild & Native & 132 \\
\hline
\end{tabular}




\begin{tabular}{|c|c|c|c|c|c|c|}
\hline $\begin{array}{l}\text { Bilibil } \\
\text { (muskwood) }\end{array}$ & $\begin{array}{l}\text { Guarea guidonia (L.) Sleumer * } \\
\text { (Meliaceae) }\end{array}$ & Const; Sha & Cof & Wild & Native & 53 \\
\hline $\begin{array}{l}\text { Bore } \\
\text { (arrowleaf elephant ear) }\end{array}$ & $\begin{array}{l}\text { Xanthosoma sagittifolium (L.) Schott } \\
\text { (Araceae) }\end{array}$ & Foo, Fod & Cof & Cultivated; Wild & $\begin{array}{l}\text { Native and } \\
\text { cultivated }\end{array}$ & 658 \\
\hline $\begin{array}{l}\text { Borrachero } \\
\text { (angel's trumpet) }\end{array}$ & $\begin{array}{l}\text { Brugmansia a suaveolens } \\
\text { (Humb. \& Bonpl. ex Willd.) Bercht. \& J.Presl } \\
\text { (Solanaceae) }\end{array}$ & Med; Orn & Gar & Cultivated & Native & 184 \\
\hline $\begin{array}{l}\text { Botoncito } \\
\text { (Bush clockvine) }\end{array}$ & $\begin{array}{l}\text { Thunbergia erecta (Benth.) T. Anderson } \\
\text { (Acanthaceae) }\end{array}$ & Orn & Gar & Cultivated & Cultivated & 53 \\
\hline Cabuya & $\begin{array}{l}\text { Furcraea cabuya } \text { Trel. } \\
\text { (Asparagaceae) }\end{array}$ & Med; Oth & Gar & Cultivated & $\begin{array}{l}\text { Native and } \\
\text { cultivated }\end{array}$ & 53 \\
\hline $\begin{array}{l}\text { Cacao } \\
\text { (cocoa) }\end{array}$ & $\begin{array}{l}\text { Theobroma cacao } \mathrm{L} \text {. } \\
\text { (Malvaceae) }\end{array}$ & Foo, Sha & Cof & Cultivated & $\begin{array}{l}\text { Native and } \\
\text { cultivated }\end{array}$ & 26 \\
\hline $\begin{array}{l}\text { Cachingo } \\
\text { (purple coral tree; } \\
\text { coral bean) }\end{array}$ & $\begin{array}{l}\text { Erythrina fusca Lour. }{ }^{*} \\
\text { (Fabaceae) }\end{array}$ & Med; Const & Cof & Wild & Native & 211 \\
\hline Cactus & $\begin{array}{l}\text { Opuntia cochenillifera (L.) Mill. } \\
\text { Schlumbergera truncata (Haw.) Moran } \\
\text { (Cactaceae) }\end{array}$ & Orn & Gar & Cultivated & Native & 105 \\
\hline $\begin{array}{l}\text { Café } \\
\text { (coffee) }\end{array}$ & $\begin{array}{l}\text { Coffea arabica L. } \\
\text { (Rubiaceae) }\end{array}$ & $\begin{array}{l}\text { Foo; Med; } \\
\text { Fue; Eco }\end{array}$ & Cof & Cultivated & Cultivated & 1000 \\
\hline Caimo & $\begin{array}{l}\text { Pouteria caimito (Ruiz \& Pav.) Radlk. } \\
\text { (Sapotaceae) }\end{array}$ & Foo; Fue; Sha & Cof & Cultivated & $\begin{array}{l}\text { Native and } \\
\text { cultivated }\end{array}$ & 474 \\
\hline $\begin{array}{l}\text { Caléndula } \\
\text { (pot marigold) }\end{array}$ & $\begin{array}{l}\text { Calendula officinalis } \mathrm{L} \text {. } \\
\text { (Asteraceae) }\end{array}$ & Med; Orn & Gar & Cultivated & Cultivated & 237 \\
\hline $\begin{array}{l}\text { Caleña } \\
\text { (Jamaican forget-me-not) }\end{array}$ & 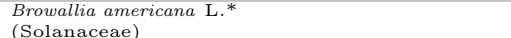 & Med; Orn & Cof & Wild & Native & 53 \\
\hline $\begin{array}{l}\text { Camarón } \\
\text { (brazilian red cloak; } \\
\text { golden shrimp plant) }\end{array}$ & $\begin{array}{l}\text { Megaskepasma erythrochlamys Lindau } \\
\text { Pachystachys lutea Nees } \\
\text { (Acanthacea) }\end{array}$ & Orn & Gar & Cultivated & Cultivated & 184 \\
\hline $\begin{array}{l}\text { Campana } \\
\text { (morning glory) }\end{array}$ & $\begin{array}{l}\text { Ipomoea indica (Burm.) Merr. } \\
\text { (Convolvulaceae) }\end{array}$ & Orn & Gar & Wild & $\begin{array}{l}\text { Native and } \\
\text { cultivated }\end{array}$ & 53 \\
\hline $\begin{array}{l}\text { Campana de oro } \\
\text { (golden trumpet) }\end{array}$ & $\begin{array}{l}\text { Allamanda cathartica } \mathrm{L} \text {. } \\
\text { (Apocynaceae) }\end{array}$ & Orn & Gar & Cultivated & $\begin{array}{l}\text { Native and } \\
\text { cultivated }\end{array}$ & 132 \\
\hline $\begin{array}{l}\text { Campanita } \\
\text { (balsam) }\end{array}$ & $\begin{array}{l}\text { Impatiens balsamina } \mathrm{L} \text {. } \\
\text { (Balaminacea) }\end{array}$ & Orn & Gar & Cultivated & Cultivated & 53 \\
\hline $\begin{array}{l}\text { Caña } \\
\text { (sugarcane) }\end{array}$ & $\begin{array}{l}\text { Saccharum officinarum L. } \\
\text { (Poaceae) }\end{array}$ & $\begin{array}{l}\text { Foo; Med; } \\
\text { Fue; Fod; Eco }\end{array}$ & Cof & Cultivated & Cultivated & 526 \\
\hline Caña agria & Costus guanaiensis Rusby* & Med & Cof; & Wild & Native & 158 \\
\hline $\begin{array}{l}\text { Capuchina ( } \\
\text { garden nasturtium) }\end{array}$ & $\begin{array}{l}\text { Tropaeolum majus L. } \\
\text { (Tropaeolaceae) }\end{array}$ & Orn & Gar & Cultivated & $\begin{array}{l}\text { Cultivated and } \\
\text { naturalized }\end{array}$ & 26 \\
\hline $\begin{array}{l}\text { Carbón } \\
\text { (charcoal) }\end{array}$ & $\begin{array}{l}\text { Zygia longifolia } \\
\text { (Humb. \& Bonpl. ex Willd.) Britton \& Rose* } \\
\text { (Fabaceae) }\end{array}$ & Fue; Const & Cof & Wild & Native & 26 \\
\hline $\begin{array}{l}\text { Carbonero } \\
\text { (powderpuff tree) }\end{array}$ & $\begin{array}{l}\text { Calliandra haematocephala Hassk. } \\
\text { (Fabaceae) }\end{array}$ & Orn & Gar & Cultivated & Cultivated & 132 \\
\hline $\begin{array}{l}\text { Cardo } \\
\text { (carrion flower) }\end{array}$ & $\begin{array}{l}\begin{array}{l}\text { Orbea variegata }(\text { L.) Haw } \\
\text { (Apocynaceae) }\end{array}\end{array}$ & Orn & Gar & Cultivated & Cultivated & 26 \\
\hline $\begin{array}{l}\text { Cartucho } \\
\text { (laceleaf, arum-lilly) }\end{array}$ & $\begin{array}{l}\text { Anthurium sp. } \\
\text { Zantedeschia aethiopica (L.) Spreng. } \\
\text { (Araceae) }\end{array}$ & Orn & Gar & Cultivated & $\begin{array}{l}\text { Native; } \\
\text { naturalized }\end{array}$ & 158 \\
\hline $\begin{array}{l}\text { Cebolla } \\
\text { (onion) }\end{array}$ & $\begin{array}{l}\text { Allium cepa } \mathrm{L} \text {. } \\
\text { Allium fistulosum } \mathrm{L} \text {. } \\
\text { (Amaryllidaceae) }\end{array}$ & Spi; Med; Eco & Orch & Cultivated & Cultivated & 895 \\
\hline Cedrillo & $\begin{array}{l}\text { Ruagea glabra Triana \& Planch. * } \\
\text { (Meliaceae) }\end{array}$ & Const; Sha & Cof & Wild & Native & 79 \\
\hline $\begin{array}{l}\text { Cedro } \\
\text { (spanish cedar) }\end{array}$ & $\begin{array}{l}\text { Cedrela odorata } \mathrm{L} . * * * \\
\text { (Meliaceae) }\end{array}$ & Med; Const; Sha & Cof & Cultivated, wild & Native & 316 \\
\hline $\begin{array}{l}\text { Chaporuto o } \\
\text { chachafruto } \\
\text { (basul) }\end{array}$ & $\begin{array}{l}\text { Erythrina edulis Triana ex Micheli* } \\
\text { (Fabaceae) }\end{array}$ & Foo & Cof & Cultivated & $\begin{array}{l}\text { Native and } \\
\text { cultivated }\end{array}$ & 79 \\
\hline $\begin{array}{l}\text { Chirimoya } \\
\text { (wild sugar-apple) }\end{array}$ & $\begin{array}{l}\text { Annona mucosa Jacq } \\
\text { (Annonaceae) }\end{array}$ & Foo & Cof & Cultivated & Native & 79 \\
\hline $\begin{array}{l}\text { Chontaduro } \\
\text { (peach palm) }\end{array}$ & $\begin{array}{l}\text { Bactris gasipaes Kunth** } \\
\text { (Arecaceae) }\end{array}$ & Foo; Eco & Cof & Wild & Native and Wild & 342 \\
\hline $\begin{array}{l}\text { Cidra } \\
\text { (citron) }\end{array}$ & $\begin{array}{l}\text { Sechium edule (Jacq.) Sw } \\
\text { (Cucurbitaceae) }\end{array}$ & Foo; Med; Fod & Cof, Orch & Cultivated & Cultivated & 316 \\
\hline $\begin{array}{l}\text { Cidrón } \\
\text { (lemon verbena) }\end{array}$ & $\begin{array}{l}\text { Aloysia citrodora Palau } \\
\text { (Verbenaceae) }\end{array}$ & Med & Cof; Orch & Cultivated; wild & Cultivated & 263 \\
\hline Cilantro & Coriandrum sativum $\mathrm{L}$. & $\mathrm{Spi} ; \mathrm{Eco}$ & Orch & Cultivated & Cultivated & 737 \\
\hline $\begin{array}{l}\text { Cilantro cimarrón } \\
\text { (culantro) }\end{array}$ & $\begin{array}{l}\text { Eryngium foetidum L.** } \\
\text { (Apiaceae) }\end{array}$ & Spi & Orch & Cultivated & $\begin{array}{l}\text { Native and } \\
\text { cultivated }\end{array}$ & 132 \\
\hline
\end{tabular}




\begin{tabular}{|c|c|c|c|c|c|c|}
\hline $\begin{array}{l}\text { Cinta } \\
\text { (spider plant) }\end{array}$ & $\begin{array}{l}\text { Chlorophytum comosum } \\
\text { (Thunb.) Jacques } \\
\text { (Asparagaceae) }\end{array}$ & Orn & Gar & Cultivated & Cultivated & 79 \\
\hline $\begin{array}{l}\text { Clavelina } \\
\text { (Carnation) }\end{array}$ & $\begin{array}{l}\text { Dianthus caryophyllus. } \mathrm{L} \text {. } \\
\text { Dianthus chinensis } \mathrm{L} . \\
\text { (Caryophyllaceae) }\end{array}$ & Orn & Gar & Cultivated & Cultivated & 263 \\
\hline Coca & $\begin{array}{l}\text { Erythroxylum coca Lam. } \\
\text { (Erythroxylaceae) }\end{array}$ & Med & Gar & Cultivated & $\begin{array}{l}\text { Native and } \\
\text { cultivated }\end{array}$ & 53 \\
\hline $\begin{array}{l}\text { Corazón herido } \\
\text { (heart of Jesus) }\end{array}$ & $\begin{array}{l}\text { Caladium bicolor Vent. } \\
\text { (Araceae) }\end{array}$ & Orn & Cof & Wild & $\begin{array}{l}\text { Native and } \\
\text { cultivated }\end{array}$ & 79 \\
\hline $\begin{array}{l}\text { Cordoncillo } \\
\text { (spiked pepper) }\end{array}$ & $\begin{array}{l}\text { Piper aduncum L.* } \\
\text { (Piperaceae) }\end{array}$ & Med & Cof & Wild & Native & 105 \\
\hline $\begin{array}{l}\text { Corona de cristo } \\
\text { (Crown of thorns) }\end{array}$ & $\begin{array}{l}\text { Euphorbia x lomi Rauh } \\
\text { (Euphorbiaceae) }\end{array}$ & Orn & Gar & Cultivated & Cultivated & 26 \\
\hline $\begin{array}{l}\text { Cortejo } \\
\text { (cape periwinkle) }\end{array}$ & $\begin{array}{l}\text { Catharanthus roseus (L.) G. Don } \\
\text { (Apocynaceae) }\end{array}$ & Orn & Gar & Cultivated & Cultivated & 184 \\
\hline $\begin{array}{l}\text { Cresta de gallo } \\
\text { (plumed cockscomb) }\end{array}$ & $\begin{array}{l}\text { Celosia argentea } \mathrm{L} \text {. } \\
\text { (Amaranthaceae) }\end{array}$ & Orn & Gar & Cultivated & Cultivated & 53 \\
\hline $\begin{array}{l}\text { Crisantemo } \\
\text { (chrysanthemum) }\end{array}$ & $\begin{array}{l}\text { Chrysanthemum spp. } \\
\text { (Asteraceae) }\end{array}$ & Orn & Gar & Cultivated & Cultivated & 105 \\
\hline $\begin{array}{l}\text { Croto } \\
\text { (garden croton) }\end{array}$ & $\begin{array}{l}\text { Codiaeum variegatum } \\
\text { (L.) Rumph. ex A. Juss. } \\
\text { (Euphorbiaceae) }\end{array}$ & Orn & Gar & Cultivated & Cultivated & 211 \\
\hline Curuba & $\begin{array}{l}\text { Passiffora tripartita (Juss.) Poir. * } \\
\text { (Passifloraceae) }\end{array}$ & Foo & Mar & Cultivated & $\begin{array}{l}\text { Native and } \\
\text { cultivated }\end{array}$ & 79 \\
\hline $\begin{array}{l}\text { Dalia } \\
\text { (Dahlia) }\end{array}$ & $\begin{array}{l}\text { Dahlia pinnata Cav. } \\
\text { (Asteraceae) }\end{array}$ & Orn & Gar & Cultivated & Native & 526 \\
\hline Descansé & $\begin{array}{l}\text { Alternanthera lanceolata } \\
\text { (Benth.) Schinz } \\
\text { (Amaranthaceae) }\end{array}$ & Med & Orch & Cultivated & Native & 132 \\
\hline $\begin{array}{l}\text { Duranta } \\
\text { (Golden dewdrop) }\end{array}$ & $\begin{array}{l}\text { Duranta repens L.** } \\
\text { (Verbenaceae) }\end{array}$ & Orn & Gar & Cultivated & Native & 26 \\
\hline $\begin{array}{l}\text { Escoba } \\
\text { (arrowleaf sida) }\end{array}$ & $\begin{array}{l}\text { Sida rhombiafolia L.* } \\
\text { (Malvaceae) }\end{array}$ & Oth & Cof & Wild & Native & 132 \\
\hline $\begin{array}{l}\text { Espinaca } \\
\text { (spinach) }\end{array}$ & $\begin{array}{l}\text { Spinacia oleracea } \mathrm{L} \text {. } \\
\text { (Amaranthaceae) }\end{array}$ & Foo & Orch & Cultivated & Cultivated & 158 \\
\hline $\begin{array}{l}\text { Eucalipto } \\
\text { (eucalyptus) }\end{array}$ & $\begin{array}{l}\text { Eucalyptus sp. } \\
\text { (Myrtaceae) }\end{array}$ & Med; Fue; Con & Cof & Cultivated & Cultivated & 684 \\
\hline $\begin{array}{l}\text { Frambuesa } \\
\text { (raspberry) }\end{array}$ & $\begin{array}{l}\text { Rubus rosifolius Sm. } \\
\text { (Rosaceae) }\end{array}$ & Foo & Orch & Cultivated & $\begin{array}{l}\text { Naturalized and } \\
\text { adventitious }\end{array}$ & 26 \\
\hline Francesina & $\begin{array}{l}\text { Brunfelsia grandiflora D. Don. } \\
\text { (Solanaceae) }\end{array}$ & Orn & Gar & Cultivated & $\begin{array}{l}\text { Native and } \\
\text { cultivated }\end{array}$ & 263 \\
\hline $\begin{array}{l}\text { Fríjol } \\
\text { (bean) }\end{array}$ & $\begin{array}{l}\text { Phaseolus vulgaris } \mathrm{L} \text {. } \\
\text { (Fabaceae) }\end{array}$ & Foo & Cof; Orch & Cultivated & Cultivated & 684 \\
\hline $\begin{array}{l}\text { Fucsia } \\
\text { (fuchsia) }\end{array}$ & $\begin{array}{l}\text { Fuchsia sp. } \\
\text { (Onagraceae) }\end{array}$ & Orn & Gar & Cultivated & Native & 105 \\
\hline $\begin{array}{l}\text { Geranio } \\
\text { (geranium) }\end{array}$ & $\begin{array}{l}\text { Pelargonium } \mathrm{x} \text { hortorum L.H. Bailey } \\
\text { (Geraniaceae) }\end{array}$ & Med; Orn & Gar & Cultivated & Cultivated & 342 \\
\hline $\begin{array}{l}\text { Girasol } \\
\text { (sunflower) }\end{array}$ & $\begin{array}{l}\text { Helianthus annuus } \mathrm{L} \text {. } \\
\text { (Asteraceae) }\end{array}$ & Orn; Fod & Gar & Cultivated & Cultivated & 211 \\
\hline $\begin{array}{l}\text { Gólgota } \\
\text { (hibiscus) }\end{array}$ & $\begin{array}{l}\text { Abutiton hybridum Hort. ex Voss } \\
\text { Hibiscus rosasinensis L. } \\
\text { (Malvaceae) }\end{array}$ & Med; Orn & Gar & Cultivated & Cultivated & 421 \\
\hline $\begin{array}{l}\text { Granadilla } \\
\text { (sweet granadilla) }\end{array}$ & $\begin{array}{l}\text { Passiflora ligularis Juss. } \\
\text { (Passifloraceae) }\end{array}$ & Foo & Cof; Orch & Cultivated & $\begin{array}{l}\text { Native and } \\
\text { cultivated }\end{array}$ & 184 \\
\hline Guacamayo & $\begin{array}{l}\text { Croton magdalenensis Müll. Arg.* } \\
\text { (Euphorbiaceae) }\end{array}$ & Fue; Con; Sha & Cof & Wild & Native & 211 \\
\hline $\begin{array}{l}\text { Guadua } \\
\text { (guadua bamboo) }\end{array}$ & $\begin{array}{l}\text { Guadua angustifolia Kunth* } \\
\text { (Paceae) }\end{array}$ & $\begin{array}{l}\text { Med; Fue; } \\
\text { Con; Eco }\end{array}$ & Cof; & Cultivated & Native & 737 \\
\hline $\begin{array}{l}\text { Guamo } \\
\text { (ice cream vean) }\end{array}$ & $\begin{array}{l}\text { Inga densiflora Benth.* } \\
\text { Inga edulis Mart.* } \\
\text { (Fabaceae) }\end{array}$ & Foo; Fue; Sha & Cof & Cultivated & $\begin{array}{l}\text { Native and } \\
\text { cultivated }\end{array}$ & 789 \\
\hline $\begin{array}{l}\text { Guanábana } \\
\text { (soursop) }\end{array}$ & $\begin{array}{l}\text { Annona muricata } \mathrm{L} \\
\text { (Annonaceae) }\end{array}$ & Foo; Med; Eco & Cof & Cultivated & Native & 447 \\
\hline Guasco & $\begin{array}{l}\text { Gautteria alta R.E. Fr. } \\
\text { (Annonaceae) }\end{array}$ & Fue; Con & Cof & Wild & Native (endemic) & 79 \\
\hline $\begin{array}{l}\text { Guayabo } \\
\text { (guava) }\end{array}$ & $\begin{array}{l}\text { Psidium guajava } \mathrm{L} . \\
\text { (Myrtaceae) }\end{array}$ & Med; Fue; Sha & Cof & Cultivated & Cultivated & 711 \\
\hline $\begin{array}{l}\text { Guineo } \\
\text { (banana) }\end{array}$ & $\begin{array}{l}\text { Musa accminata Colla } \\
\text { (Musaceae) }\end{array}$ & Foo; Med & Cof & Cultivated & Cultivated & 105 \\
\hline $\begin{array}{l}\text { Gusano } \\
\text { (chenille plant) }\end{array}$ & $\begin{array}{l}\text { Acalypha hispida Burm. f. } \\
\text { (Euphorbiaceae) }\end{array}$ & Orn & Gar & Cultivated & Cultivated & 26 \\
\hline $\begin{array}{l}\text { Habichuela } \\
\text { (common vean) }\end{array}$ & $\begin{array}{l}\text { Phaseolus vulgaris 'vulgaris' L. } \\
\text { (Fabaceae) }\end{array}$ & Foo & Orch & Cultivated & Cultivated & 447 \\
\hline $\begin{array}{l}\text { Helecho } \\
\text { (sword fern) }\end{array}$ & $\begin{array}{l}\text { Nephrolepis exaltata (L.) Schott } \\
\text { (Nephrolepidaceae) }\end{array}$ & Orn & Gar & Cultivated & Native & 26 \\
\hline
\end{tabular}




\begin{tabular}{|c|c|c|c|c|c|c|}
\hline $\begin{array}{l}\begin{array}{l}\text { Helecho peludo } \\
\text { (yarrow) }\end{array} \\
\text { (n) }\end{array}$ & $\begin{array}{l}\text { Achillea millefolium } \mathrm{L} \text {. } \\
\text { (Asteraceae) }\end{array}$ & Orn & Gar & Wild & Cultivated & 53 \\
\hline $\begin{array}{l}\text { Higuerillo } \\
\text { (castor vean) }\end{array}$ & $\begin{array}{l}\text { Ricinus communis } \mathrm{L} \text {. } \\
\text { (Euphorbiaceae) }\end{array}$ & Fue; Oth & Cof & Cultivated & $\begin{array}{l}\text { Cultivated and } \\
\text { naturalized }\end{array}$ & 105 \\
\hline $\begin{array}{l}\text { Higuillo } \\
\text { (mountain papaya) }\end{array}$ & $\begin{array}{l}\text { Vasconcellea pubescens A. DC. } \\
\text { (Caricaceae) }\end{array}$ & Foo & Cof & Wild & $\begin{array}{l}\text { Native and } \\
\text { cultivated }\end{array}$ & 26 \\
\hline $\begin{array}{l}\text { Hinojo } \\
\text { (fennel) }\end{array}$ & $\begin{array}{l}\text { Foeniculum vulgare Mill. } \\
\text { (Apiaceae) }\end{array}$ & Med & Orch; Gar & Cultivated & Cultivated & 79 \\
\hline $\begin{array}{l}\text { Hoja santa } \\
\text { (cathedral bell plant) }\end{array}$ & $\begin{array}{l}\text { Kalanchoe pinnata (Lam.) Pers. } \\
\text { (Crassulaceae) }\end{array}$ & Med; Orn & Gar & Cultivated & $\begin{array}{l}\text { Naturalized and } \\
\text { adventitious }\end{array}$ & 79 \\
\hline $\begin{array}{l}\text { Hortensia } \\
\text { (mopead hydrangea) }\end{array}$ & $\begin{array}{l}\text { Hydrangea macrophylla (Thunb.) Ser. } \\
\text { (Hydrangeaceae) }\end{array}$ & Orn & Gar & Cultivated & Cultivated & 184 \\
\hline Huevo de perro & $\begin{array}{l}\text { Thevetia ahouaia (L.) A. DC. } \\
\text { (Apocynaceae) }\end{array}$ & Orn & Gar & Cultivated & Native & 53 \\
\hline $\begin{array}{l}\text { Iraca } \\
\text { (Panama hat palm) }\end{array}$ & $\begin{array}{l}\text { Carludovica palmata Ruiz \& Pav.* } \\
\text { (Cyclanthaceae) }\end{array}$ & Eco; Oth & Cof & Wild & Native & 79 \\
\hline $\begin{array}{l}\text { Lechero } \\
\text { (tropical smoke bush) }\end{array}$ & $\begin{array}{l}\begin{array}{l}\text { Euphorbia cotinifolia L.* } \\
\text { (Euphorbiaceae) }\end{array} \\
\text { (E) }\end{array}$ & Med; Orn & Cof & Cultivated; wild & Native & 79 \\
\hline $\begin{array}{l}\text { Lechuga } \\
\text { (lettuce) }\end{array}$ & $\begin{array}{l}\text { Lactuca sativa } \mathrm{L} . \\
\text { (Asteraceae) }\end{array}$ & Foo; Med & Orch & Cultivated & Cultivated & 368 \\
\hline $\begin{array}{l}\text { Lechuga ornamental } \\
\text { (lettuce) }\end{array}$ & $\begin{array}{l}\text { Lactuca sp. } \\
\text { (Asteraceae) }\end{array}$ & Orn & Gar & Cultivated & Cultivated & 26 \\
\hline $\begin{array}{l}\text { Limón } \\
\text { (key lime) }\end{array}$ & $\begin{array}{l}\text { Citrus } \times \text { aurantifolia (Christm.) Swingle } \\
\text { (Rutaceae) }\end{array}$ & Foo; Med & Cof & Cultivated & Cultivated & 789 \\
\hline $\begin{array}{l}\text { Limoncillo } \\
\text { (lemongrass) }\end{array}$ & $\begin{array}{l}\text { Cymbopogon citratus (DC.) Stapf } \\
\text { (Poaceae) }\end{array}$ & Med & Orch & Cultivated & Cultivated & 316 \\
\hline $\begin{array}{l}\text { Llantén } \\
\text { (broadleaf plantain) }\end{array}$ & $\begin{array}{l}\text { Plantago major } \mathrm{L} \text {. } \\
\text { (Plantaginaceae) }\end{array}$ & Med & Orch & Wild & Naturalized & 79 \\
\hline Lulo & $\begin{array}{l}\text { Solanum quitoense Lam. } \\
\text { (Solanaceae) }\end{array}$ & Foo & Cof & Cultivated & $\begin{array}{l}\text { Native and } \\
\text { cultivated }\end{array}$ & 158 \\
\hline $\begin{array}{l}\text { Maíz } \\
\text { (maize) }\end{array}$ & $\begin{array}{l}\text { Zea mays } \mathrm{L} \cdot{ }^{*} \\
\text { (Poaceae) }\end{array}$ & Foo; Fod & Cof & Cultivated & $\begin{array}{l}\text { Native and } \\
\text { cultivated }\end{array}$ & 605 \\
\hline $\begin{array}{l}\text { Mandarina } \\
\text { (tangerine) }\end{array}$ & $\begin{array}{l}\text { Citrus reticulata Blanco } \\
\text { (Rutaceae) }\end{array}$ & Food; Med & Cof & Cultivated & Cultivated & 526 \\
\hline $\begin{array}{l}\text { Mango } \\
\text { (mango) }\end{array}$ & $\begin{array}{l}\text { Mangifera indicica } \mathrm{L} \text {. } \\
\text { (Anacardiacea) }\end{array}$ & Foo; Med; Sha & Cof & Cultivated & Cultivated & 658 \\
\hline $\begin{array}{l}\text { Maní } \\
\text { (peanut) }\end{array}$ & $\begin{array}{l}\text { Arachis hypogaea } \mathrm{L} \text {. } \\
\text { (Fabaceae) }\end{array}$ & Foo & Mar & Cultivated & Cultivated & 53 \\
\hline $\begin{array}{l}\text { Manzana } \\
\text { (apple) }\end{array}$ & $\begin{array}{l}\text { Malus pumila Mill. } \\
\text { (Rosaceae) }\end{array}$ & Foo & Mar & Cultivated & Cultivated & 211 \\
\hline $\begin{array}{l}\text { Manzanilla } \\
\text { (chamomile) }\end{array}$ & $\begin{array}{l}\text { Matricaria recutita L. } \\
\text { (Asteraceae) }\end{array}$ & Med & Orch; Gar & Cultivated & Adventitious & 237 \\
\hline $\begin{array}{l}\text { Maracuyá } \\
\text { (passion fruit) }\end{array}$ & $\begin{array}{l}\text { Passiflora edulis Sims } \\
\text { (Passifforaceae) }\end{array}$ & Foo; Med & Orch & Cultivated & $\begin{array}{l}\text { Native and } \\
\text { cultivated }\end{array}$ & 421 \\
\hline $\begin{array}{l}\text { Margarita } \\
\text { (marguerite Daisy, } \\
\text { oxeye daisy) }\end{array}$ & 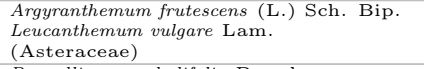 & Orn & Gar & Cultivated & Cultivated & 105 \\
\hline $\begin{array}{l}\text { Mariguano } \\
\text { (west Indian sumac) }\end{array}$ & $\begin{array}{l}\text { Brunellia comocladifolia Bonpl. } \\
\text { (Brunelliaceae) }\end{array}$ & Sha & Cof; For & Wild & Native & 26 \\
\hline $\begin{array}{l}\text { Mayo } \\
\text { (Christmas orchid) }\end{array}$ & $\begin{array}{l}\text { Cattleya trianae Linden \& Rchb. f.*** } \\
\text { (Orchidaceae) }\end{array}$ & Orn & Cof; Gar & Cultivated & $\begin{array}{l}\text { Native and } \\
\text { cultivated } \\
\text { (endemic) }\end{array}$ & 237 \\
\hline $\begin{array}{l}\text { Mejorana } \\
\text { (majoram) }\end{array}$ & 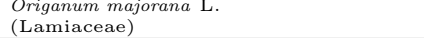 & Med & Cof; Orch & Cultivated & Cultivated & 105 \\
\hline $\begin{array}{l}\text { Mora } \\
\text { (andean raspberry) }\end{array}$ & $\begin{array}{l}\text { Rubus glaucus Benth. } \\
\text { (Rosaceae) }\end{array}$ & Foo & Mar & Cultivated & $\begin{array}{l}\text { Native and } \\
\text { cultivated }\end{array}$ & 211 \\
\hline $\begin{array}{l}\text { Mora silvestre } \\
\text { (wild berry) }\end{array}$ & $\begin{array}{l}\text { Rubus urticiciflius Poir. } \\
\text { (Rosacea) }\end{array}$ & Foo; Med & Cof & Wild & Native & 105 \\
\hline Nacedero & $\begin{array}{l}\text { Trichanthera gigantea (Bonpl.) Nees* } \\
\text { (Acanthaceae) }\end{array}$ & Fue; Con; Sha & Cof & Cultivated & Native & 79 \\
\hline $\begin{array}{l}\text { Naranja } \\
\text { (bitter orange, } \\
\text { sweet orange } \\
\text { and pummelo) }\end{array}$ & $\begin{array}{l}\text { Citrus } \times \text { sinensis }(\mathrm{L} \text {.) Osbeck } \\
\text { Citrus } \times \text { aurantium } \mathrm{L} \text {. } \\
\text { Citrus grandis } \text { (L.) Osbeck } \\
\text { (Rutaceae) }\end{array}$ & $\begin{array}{l}\text { Foo; Fue; } \\
\text { Eco; Med; } \\
\text { Sha; Oth }\end{array}$ & Cof & Cultivated & Cultivated & 921 \\
\hline $\begin{array}{l}\text { Navideña } \\
\text { (poinsettia) }\end{array}$ & $\begin{array}{l}\text { Euphorbia pulcherrima Willd. ex Klotzsch } \\
\text { (Euphorbiaceae) }\end{array}$ & Orn & Gar & Cultivated & Cultivated & 132 \\
\hline $\begin{array}{l}\text { Nogal } \\
\text { (salmwood) }\end{array}$ & $\begin{array}{l}\text { Cordia alliodora (Ruiz \& Pav.) Oken } \\
\text { (Cordiaceae) }\end{array}$ & Med; Con; Sha & Cof & Wild & Native & 421 \\
\hline $\begin{array}{l}\text { Orégano } \\
\text { (oregano) }\end{array}$ & $\begin{array}{l}\text { Origanum vulgare } \mathrm{L} \\
\text { (Lamiaceae) }\end{array}$ & Spi; Med & Orch & Cultivated & Cultivated & 526 \\
\hline $\begin{array}{l}\begin{array}{l}\text { Orquideas } \\
\text { (orchids) }\end{array} \\
\text { (a) }\end{array}$ & $\begin{array}{l}\text { Epidendrum catillus Rchb. f. \& Warsz. } \\
\text { Mapinguari desvauxianus } \\
\text { (Rchb. f.) Carnevali \& R.B. Singer } \\
\text { Oncidium sp. (Orchidaceae) }\end{array}$ & Orn & Cof, Gar, For & Wild & $\begin{array}{l}\text { Native (Endemic); } \\
\text { Native and } \\
\text { cultivated; } \\
\text { native }\end{array}$ & 79 \\
\hline $\begin{array}{l}\text { Pacunga } \\
\text { (black-jack) }\end{array}$ & $\begin{array}{l}\text { Bidens pilosa } \mathrm{L} . * \\
\text { (Asteraceae) }\end{array}$ & Med; Fod & Cof & Wild & Adventitious & 211 \\
\hline
\end{tabular}




\begin{tabular}{|c|c|c|c|c|c|c|}
\hline Paico & $\begin{array}{l}\text { Chenopodium ambrosioides L.* } \\
\text { (Amaranthaceae) }\end{array}$ & Med & Caf; Hue & Sembrada & Naturalizada & 421 \\
\hline Pajarito; Muerdago & $\begin{array}{l}\text { Oryctanthus aff. spicatus (Jacq.) Eichler } \\
\text { (Loranthaceae) }\end{array}$ & Med & Caf; & Silvestre & Nativa & 79 \\
\hline $\begin{array}{l}\text { Palma areca } \\
\text { (yellow palm) }\end{array}$ & $\begin{array}{l}\text { yypsis lutescens } \\
\text { (H. Wendl.) Beentje \& J. Dransf. } \\
\text { (Arecaceae) }\end{array}$ & Orn & Gar & Cultivated & Cultivated & 53 \\
\hline $\begin{array}{l}\text { Palma maicera } \\
\text { (cornstalk dracaena, } \\
\text { corn plant) }\end{array}$ & $\begin{array}{l}\text { Dracaena fragrans (L.) Ker Gawl. } \\
\text { (Asparagacaee) }\end{array}$ & Orn & Gar & Cultivated & Cultivated & 26 \\
\hline $\begin{array}{l}\text { Palma morada } \\
\text { (palm lilly) }\end{array}$ & $\begin{array}{l}\text { Cordyline rubra Otto \& A. Dietr. } \\
\text { (Asparagaceae) }\end{array}$ & Orn & Cof; Gar & Cultivated & Cultivated & 158 \\
\hline $\begin{array}{l}\text { Palma roja } \\
\text { (Ti plant) }\end{array}$ & $\begin{array}{l}\text { Cordyline fruticosa }(\text { L.) A. Chev. } \\
\text { (Asparagaceae) }\end{array}$ & Orn & Cof; Gar & Cultivated & Cultivated & 132 \\
\hline $\begin{array}{l}\text { Papa } \\
\text { (potato) }\end{array}$ & 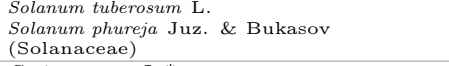 & Foo; Fod; Med & Orch; Mar & Cultivated & Cultivated & 737 \\
\hline $\begin{array}{l}\text { Papayo } \\
\text { (papaya) }\end{array}$ & $\begin{array}{l}\text { Carica papaya } \mathrm{L}{ }^{*} \\
\text { (Caricaceae) }\end{array}$ & Foo & Cof & Cultivated & $\begin{array}{l}\text { Native and } \\
\text { cultivated }\end{array}$ & 421 \\
\hline $\begin{array}{l}\text { Paramo } \\
\text { (asparagus fern) }\end{array}$ & $\begin{array}{l}\text { Asparagus densiflorus (Kunth) Jessop } \\
\text { (Asparagaceae) }\end{array}$ & Orn & Gar & Cultivated & Cultivated & 53 \\
\hline $\begin{array}{l}\text { Pasto } \\
\text { (grass, guinea grass) }\end{array}$ & $\begin{array}{l}\text { Cenchrus sp. } \\
\text { Panicum maximum Jacq.* } \\
\text { (Poaceae) }\end{array}$ & Fod & Cof & Cultivated & $\begin{array}{l}\text { Naturalized and } \\
\text { adventitious }\end{array}$ & 237 \\
\hline $\begin{array}{l}\text { Pepino } \\
\text { (cucumber) }\end{array}$ & $\begin{array}{l}\text { Cucumis sativus } \mathrm{L} \text {. } \\
\text { (Cucurbitaceae) }\end{array}$ & Foo & Mar & Cultivated & Cultivated & 105 \\
\hline $\begin{array}{l}\text { Perejil } \\
\text { (parsley) }\end{array}$ & $\begin{array}{l}\text { Petroselinum crispum (Mill.) Fuss } \\
\text { (Apiaceae) }\end{array}$ & Spi; Med & Orch & Cultivated & Cultivated & 79 \\
\hline Piel de sapo & $\begin{array}{l}\text { Justicia sp. } \\
\text { (Acanthaceae) }\end{array}$ & Orn & Gar & Cultivated & Native & 26 \\
\hline $\begin{array}{l}\text { Pino } \\
\text { (White cedar) }\end{array}$ & $\begin{array}{l}\text { Cupressus lusitanica Mill. } \\
\text { (Cupressaceae) }\end{array}$ & $\begin{array}{l}\text { Fue; Con; } \\
\text { Med; Orn }\end{array}$ & Gar & Cultivated & Cultivated & 500 \\
\hline $\begin{array}{l}\text { Piña } \\
\text { (pinapple) }\end{array}$ & $\begin{array}{l}\text { Ananas comosus (L.) Merr. } \\
\text { (Bromeliaceae) }\end{array}$ & Foo; Med; Oth & Cof & Cultivated & Cultivated & 421 \\
\hline $\begin{array}{l}\text { Plátano } \\
\text { (banana) }\end{array}$ & $\begin{array}{l}\text { Musa balbisiana Colla } \\
\text { (Musaceae) }\end{array}$ & $\begin{array}{l}\text { Foo; Fod; Eco; } \\
\text { Med; Oth }\end{array}$ & Cof & Cultivated & Cultivated & 947 \\
\hline Poleo & $\begin{array}{l}\text { Satureja brownei (Sw.) Briq. * } \\
\text { (Lamiaceae) }\end{array}$ & Spi; Med & Cof & Cultivated & Native & 105 \\
\hline $\begin{array}{l}\text { Pronto alivio } \\
\text { (bushy matgrass) }\end{array}$ & $\begin{array}{l}\text { Lippia alba } \\
\text { (Mill.) N.E. Br. ex Britton \& P. Wilson* } \\
\text { (Verbenaceae) }\end{array}$ & Med & Cof; Orch & Wild & Native & 342 \\
\hline $\begin{array}{l}\text { Remolacha } \\
\text { (beet) }\end{array}$ & $\begin{array}{l}\text { Beta vulgaris } \mathrm{L} \text {. } \\
\text { (Amaranthaceae) }\end{array}$ & Foo & Mar & Cultivated & Cultivated & 53 \\
\hline $\begin{array}{l}\text { Repollo } \\
\text { (cabbage) }\end{array}$ & $\begin{array}{l}\text { Brassica oleracea 'capitata' L. } \\
\text { (Brassicaceae) }\end{array}$ & Foo; Fod; Eco & Orch; Mar & Cultivated & Cultivated & 368 \\
\hline $\begin{array}{l}\text { Resucitado } \\
\text { (wax mallow) }\end{array}$ & $\begin{array}{l}\text { Malvaviscus arboreus Cav. } \\
\text { (Malvaceae) }\end{array}$ & Med & Gar & Cultivated & Cultivated & 26 \\
\hline Riñón & $\begin{array}{l}\text { Ruellia blechum L.* } \\
\text { Justicia secunda Vahl } \\
\text { (Acanthaceae) }\end{array}$ & Med & Orch; Gar & Cultivated & Native & 53 \\
\hline $\begin{array}{l}\text { Roble } \\
\text { (oak) }\end{array}$ & $\begin{array}{l}\text { Quercus humboldtii Bonpl.** } \\
\text { (Fagaceae) }\end{array}$ & Con & For & Wild & $\begin{array}{l}\text { Native and } \\
\text { cultivated }\end{array}$ & 632 \\
\hline $\begin{array}{l}\text { Romero } \\
\text { (rosemary) }\end{array}$ & $\begin{array}{l}\text { Rosmarinus officinalis } \mathrm{L} \text {. } \\
\text { (Lamiaceae) }\end{array}$ & Med & Gar & Cultivated & Cultivated & 474 \\
\hline $\begin{array}{l}\text { Roso } \\
\text { (rose) }\end{array}$ & $\begin{array}{l}\text { Rosa } \times \text { alba } \mathrm{L} \text {. Rosa } \times \text { damascena Mill. } \\
\text { Rosa sp. (Rosaceae) }\end{array}$ & Med; Orn & Gar & Cultivated & Cultivated & 553 \\
\hline Rúchica & $\begin{array}{l}\text { Monnina fastigiata (Bonpl.) DC. } \\
\text { (Polygalaceae) }\end{array}$ & Med & For; Mar & Wild & Native (Endemic) & 26 \\
\hline $\begin{array}{l}\text { Ruda } \\
\text { (common rue) }\end{array}$ & $\begin{array}{l}\text { Ruta graveolens } \mathrm{L} \text {. } \\
\text { (Rutaceae) }\end{array}$ & Med & Cof; Orch & Cultivated & Cultivated & 263 \\
\hline $\begin{array}{l}\text { Sábila } \\
\text { (aloe) }\end{array}$ & $\begin{array}{l}\text { Aloe maculata All. } \\
\text { Aloe era ( (.). Burm. f. } \\
\text { Aloe sp. (Asphodelaceae) }\end{array}$ & Med & Orch; Gar & Cultivated & Cultivated & 553 \\
\hline $\begin{array}{l}\text { Salvajina } \\
\text { (Spanish moss) }\end{array}$ & $\begin{array}{l}\text { Tillandsia usneoides (L.) L.* } \\
\text { (Bromeliaceae) }\end{array}$ & Oth & Cof & Wild & Native & 26 \\
\hline $\begin{array}{l}\text { Sauco } \\
\text { (black elder) }\end{array}$ & $\begin{array}{l}\text { Sambucusu nigra L.* } \\
\text { (Adoxaceae) }\end{array}$ & Med & Gar & Cultivated & Cultivated & 263 \\
\hline $\begin{array}{l}\text { Siete cueros } \\
\text { (silver leafhead } \\
\text { princess flower) }\end{array}$ & $\begin{array}{l}\text { Tibouchina heteromalla (D. Don) Cogn. } \\
\text { Tibouchina urvilleana (DC.) Cogn. } \\
\text { (Melastomataceae) }\end{array}$ & Orn & Gar & Cultivated & Cultivated & 105 \\
\hline $\begin{array}{l}\text { Sorgo } \\
\text { (sorghum, great Millet) }\end{array}$ & $\begin{array}{l}\text { Sorghum bicolor (L.) Moench } \\
\text { (Poaceae) }\end{array}$ & Fod & Cof; Orch & Cultivated & $\begin{array}{l}\text { Naturalized and } \\
\text { adventitious }\end{array}$ & 53 \\
\hline $\begin{array}{l}\text { Té } \\
\text { (calico plant) }\end{array}$ & $\begin{array}{l}\text { Alternanthera bettzickiana } \\
\text { (Regel) G. Nicholson } \\
\text { (Amaranthaceae) }\end{array}$ & Orn & Gar & Cultivated & Cultivated & 132 \\
\hline
\end{tabular}




\begin{tabular}{|c|c|c|c|c|c|c|}
\hline $\begin{array}{l}\text { Tomate } \\
\text { (tomato) }\end{array}$ & $\begin{array}{l}\text { Solanum lycopersicum L. } \\
\text { (Solanaceae) }\end{array}$ & Foo; Med & Cof & Cultivated & Cultivated & 474 \\
\hline $\begin{array}{l}\text { Tomate Cherry } \\
\text { (cherry tomato) }\end{array}$ & $\begin{array}{l}\text { Solanum lycopersicum 'cerasiforme } \\
\text { D.M. Spooner, G.J. Anderson \& R.K. Jansen } \\
\text { (Solanaceae) }\end{array}$ & Foo & Orch; Gar & Cultivated & Cultivated & 289 \\
\hline $\begin{array}{l}\text { Tomate de árbol } \\
\text { (tree tomato) }\end{array}$ & $\begin{array}{l}\text { Solanum betaceum Cav. } \\
\text { (Solanaceae) }\end{array}$ & Foo; Med & Cof; Orch & Cultivated & Cultivated & 316 \\
\hline $\begin{array}{l}\text { Tomillo } \\
\text { (thyme) }\end{array}$ & $\begin{array}{l}\text { Thymus vulgaris L. } \\
\text { (Lamiaceae) }\end{array}$ & Spi; Med & Gar & Cultivated & Cultivated & 368 \\
\hline $\begin{array}{l}\text { Toronjil } \\
\text { (melissa) }\end{array}$ & $\begin{array}{l}\text { Melissa sp. } \\
\text { (Lamiaceae) }\end{array}$ & Med & Cof & Cultivated & Cultivated & 184 \\
\hline $\begin{array}{l}\text { Totumo } \\
\text { (calabash tree) }\end{array}$ & $\begin{array}{l}\text { Crescentia cujete } \mathrm{L} .{ }^{*} \\
\text { (Bignoniaceae) }\end{array}$ & Oth & Orch; Gar & Cultivated & $\begin{array}{l}\text { Native and } \\
\text { cultivated }\end{array}$ & 26 \\
\hline $\begin{array}{l}\text { Tuna } \\
\text { (barbary fig) }\end{array}$ & $\begin{array}{l}\text { Opuntia ficus-indica (L.) Mill. } \\
\text { (Cactaceae) }\end{array}$ & Foo; Orn & Gar & Cultivated & Cultivated & 26 \\
\hline $\begin{array}{l}\text { Uva } \\
\text { (grape) }\end{array}$ & $\begin{array}{l}\text { Vitis vinifera L. } \\
\text { (Vitaceae) }\end{array}$ & Foo & Mar & Cultivated & Cultivated & 158 \\
\hline Valeriana & $\begin{array}{l}\text { Scutellaria agrestis A. St.-Hil. ex Benth. } \\
\text { (Lamiaceae) }\end{array}$ & Med & Cof & Cultivated & Cultivated & 79 \\
\hline $\begin{array}{l}\text { Venturosa } \\
\text { (common lantana) }\end{array}$ & $\begin{array}{l}\text { Lantana camara } \mathrm{L} . * \\
\text { (Verbenaceae) }\end{array}$ & Med & Cof & Wild & Native & 26 \\
\hline $\begin{array}{l}\text { Veranera } \\
\text { (bouganvillea; } \\
\text { chinese hat plant) }\end{array}$ & $\begin{array}{l}\text { Bougainvillea glabra Choisy } \\
\text { (Nyctaginaceae) } \\
\text { Holmskioldia sanguinea Retz. } \\
\text { (Lamiaceae) }\end{array}$ & Orn & Gar & Cultivated & Cultivated & 342 \\
\hline $\begin{array}{l}\text { Verbena } \\
\text { (seashore vervain) }\end{array}$ & $\begin{array}{l}\text { Verbena litoralis Kunth.* } \\
\text { (Verbenaceae) }\end{array}$ & Med & Cof & Wild & Native & 211 \\
\hline $\begin{array}{l}\text { Verdolaga } \\
\text { (common purslane) }\end{array}$ & $\begin{array}{l}\text { Portulaca oleracea } \mathrm{L} \text {. } \\
\text { (Portulacaceae) }\end{array}$ & Med; Orn & Gar & Cultivated & Naturalized & 263 \\
\hline $\begin{array}{l}\text { Vidrio } \\
\text { (moss-rose purslane) }\end{array}$ & $\begin{array}{l}\text { Portulaca grandiflora Hook. } \\
\text { (Portulacaceae) }\end{array}$ & Orn & Gar & Cultivated & CUltivated & 26 \\
\hline $\begin{array}{l}\text { Vispero } \\
\text { (loquat) }\end{array}$ & $\begin{array}{l}\text { Eriobotrya japonica (Thunb.) Lindl. } \\
\text { (Rosaceae) }\end{array}$ & Fue; Oth & Cof & Cultivated & Cultivated & 79 \\
\hline $\begin{array}{l}\text { Viuda } \\
\text { (violet petunia; petunia) }\end{array}$ & $\begin{array}{l}\text { Petunia violacea Lindl. } \\
\text { Petunia } \times \text { hybrida Hort. ex E. Vilm. } \\
\text { (Solanaceae) }\end{array}$ & Orn & Gar & Cultivated & Cultivated & 184 \\
\hline Votatumbo & $\begin{array}{l}\text { Aegiphila truncata Moldenke } \\
\text { (Lamiaceae) }\end{array}$ & Fue; Con; Sha & Cof & Wild & Native (endemic) & 53 \\
\hline $\begin{array}{l}\text { Yarumo } \\
\text { (trumpet tree) }\end{array}$ & $\begin{array}{l}\text { Cecropia peltata } \mathrm{L} . * \\
\text { (Urticaceae) }\end{array}$ & Med; Fue & Cof & Wild & Native & 158 \\
\hline $\begin{array}{l}\text { Yedra } \\
\text { (geranium) }\end{array}$ & $\begin{array}{l}\text { Pelargonium × peltatum } \\
\text { (L.) L'Hér. ex Aiton } \\
\text { (Geraniaceae) }\end{array}$ & Orn & Gar & Cultivated & Cultivated & 184 \\
\hline $\begin{array}{l}\text { Yerba de chivo } \\
\text { (billygoat weed; } \\
\text { chickweed) }\end{array}$ & $\begin{array}{l}\text { Ageratum conyzoides L.* } \\
\text { (Asteraceae) }\end{array}$ & Med & Cof & Wild & Native & 132 \\
\hline $\begin{array}{l}\text { Yerbabuena } \\
\text { (spearmint) }\end{array}$ & $\begin{array}{l}\text { Mentha spicata } \mathrm{L} . \\
\text { (Damiaceae) }\end{array}$ & Spi; Med & Cof & Cultivated & Cultivated & 711 \\
\hline Yerbagolpe & $\begin{array}{l}\text { Pseudelephantopus spiralis } \\
\text { (Less.) Cronquist } \\
\text { (Asteraceae) }\end{array}$ & Med & Cof; Orch & Wild & Native & 132 \\
\hline $\begin{array}{l}\text { Yerbamora } \\
\text { (american nightshade) }\end{array}$ & $\begin{array}{l}\text { Solanum americanum Mill.* } \\
\text { (Solanaceae) }\end{array}$ & Med & Cof & Wild & Native & 105 \\
\hline $\begin{array}{l}\text { Yuca } \\
\text { (cassava) }\end{array}$ & $\begin{array}{l}\text { Manihot esculenta Crantz } \\
\text { (Euphorbiaceae) }\end{array}$ & $\begin{array}{l}\text { Foo; Fod; } \\
\text { Eco; Oth }\end{array}$ & Cof & Cultivated & Native & 895 \\
\hline $\begin{array}{l}\text { Yuca ornamental } \\
\text { (coral plant) }\end{array}$ & $\begin{array}{l}\text { Jatropha multifida } \mathrm{L} \text {. } \\
\text { (Euphorbiaceae) }\end{array}$ & Orn & Gar & Cultivated & Native & 26 \\
\hline $\begin{array}{l}\text { Zanahoria } \\
\text { (carrot) }\end{array}$ & $\begin{array}{l}\text { Daucus carota } \mathrm{L} \text {. } \\
\text { (Apiaceae) }\end{array}$ & Foo; Med & Mar & Cultivated & Cultivated & 632 \\
\hline $\begin{array}{l}\text { Zapallo } \\
\text { (squash) }\end{array}$ & $\begin{array}{l}\text { Cucurbita maxima Duchesne } \\
\text { (Cucurbitaceae) }\end{array}$ & Foo & Cof; Orch & Cultivated & Cultivated & 342 \\
\hline $\begin{array}{l}\text { Zapatico } \\
\text { (peruvian zinnia) }\end{array}$ & $\begin{array}{l}\text { Zinnia peruviana (L.) L. } \\
\text { (Asteraceae) }\end{array}$ & Orn & Gar & Cultivated & $\begin{array}{l}\text { Native and } \\
\text { cultivated }\end{array}$ & 105 \\
\hline $\begin{array}{l}\text { Zarzaparrilla } \\
\text { (prickly ivy) }\end{array}$ & $\begin{array}{l}\text { Smilax sp. } \\
\text { (Smilacaceae) }\end{array}$ & Med & For & Wild & Native & 26 \\
\hline $\mathrm{S} / \mathrm{N}$ & $\begin{array}{l}\text { Abutilon megapotamicum } \\
\text { (A. Spreng.) A. St.-Hil. \& Naudin } \\
\text { (Malvaceae) } \\
\text { Artemiciaalololeuca M Bieb Ex Besser }\end{array}$ & Orn & Gar & Cultivated & Cultivated & - \\
\hline $\mathrm{S} / \mathrm{N}$ & $\begin{array}{l}\text { Artemisia hololeuca M. Bieb. Ex Besser } \\
\text { (Asteraceae) }\end{array}$ & Med; Orn & Gar & Cultivated & Cultivated & - \\
\hline $\mathrm{S} / \mathrm{N}$ & $\begin{array}{l}\text { Aster sp. } \\
\text { (Asteraceae) }\end{array}$ & Orn & Gar & Cultivated & Cultivated & - \\
\hline $\mathrm{S} / \mathrm{N}$ & $\begin{array}{l}\text { Centropogon cornutus (L.) Druce } \\
\text { (Campanulaceae) }\end{array}$ & Orn & Gar & Cultivated; Wild & Native & - \\
\hline
\end{tabular}




\begin{tabular}{|c|c|c|c|c|c|c|}
\hline $\mathrm{S} / \mathrm{N}$ & $\begin{array}{l}\text { Dussia atropurpurea } \\
\text { N. Zamora, R.T. Penn. \& C.H. Stirt. } \\
\text { (Fabaceae) }\end{array}$ & Sha & Cof & Wild & Native & - \\
\hline $\mathrm{S} / \mathrm{N}$ & $\begin{array}{l}\text { Emilia sonchifolia (L.) DC. } \\
\text { (Asteraceae) }\end{array}$ & Fod & Cof & Wild & Adventitious & - \\
\hline $\mathrm{S} / \mathrm{N}$ & $\begin{array}{l}\text { Gardenia jasminoides J. Ellis } \\
\text { (Rubiaceae) }\end{array}$ & Orn & Gar & Cultivated & Cultivated & - \\
\hline $\mathrm{S} / \mathrm{N}$ & $\begin{array}{l}\text { Gazaniaia sp. } \\
\text { (Asteraceae) }\end{array}$ & Orn & Gar & Cultivated & Cultivated & - \\
\hline $\mathrm{S} / \mathrm{N}$ & $\begin{array}{l}\text { Gomphrena globosa } \mathrm{L} . \\
\text { (Amaranthaceae) }\end{array}$ & Orn & Gar & Cultivated & Cultivated & - \\
\hline $\mathrm{S} / \mathrm{N}$ & $\begin{array}{l}\text { Justicia sp. } \\
\text { (Acanthaceae) }\end{array}$ & Orn & Gar & Cultivated & Native & - \\
\hline $\mathrm{S} / \mathrm{N}$ & $\begin{array}{l}\text { Kalanchoe blossfeldiana Poelln. } \\
\text { (Crassulaceae) }\end{array}$ & Orn & Gar & Cultivated & Cultivated & - \\
\hline $\mathrm{S} / \mathrm{N}$ & $\begin{array}{l}\text { Salvia rubescens Kunth** } \\
\text { (Lamiaceae) }\end{array}$ & Med & Gar & Cultivated & Native & - \\
\hline $\mathrm{S} / \mathrm{N}$ & $\begin{array}{l}\text { Sonchus sp. } \\
\text { (Asteraceae) }\end{array}$ & Med & Cof; Orch & Wild & Adventitious & - \\
\hline $\mathrm{S} / \mathrm{N}$ & $\begin{array}{l}\text { Symphyotrichum sp. } \\
\text { (Asteraceae) }\end{array}$ & Orn & Gar & Cultivated & Cultivated & - \\
\hline $\mathrm{S} / \mathrm{N}$ & $\begin{array}{l}\text { Torenia fournieai Linden ex E. Fourn. } \\
\text { (Linderniacea) }\end{array}$ & Orn & Gar & Cultivated & Cultivated & - \\
\hline
\end{tabular}

Ethnobotanical categories: Food (Foo); Spices (Spi); Medicinal (Med); Ornamental (Orn); Fuel (Fue); Fodder (Fod); Construction (Con); Economic (Eco); Shade (Sha); Other (Otr) Management space: Coffee plantation (Cof); Forest (For); Garden (Gar); Orchard (Orch); Market (Mar)
Conservation status: *Minor concern, **Vulnerable, ***Endangered.

English if available: All common names in English refer to the vernacular ways to call the scientific species or genera that are cited. 